NBER WORKING PAPER SERIES

\title{
EMPLOYMENT CYCLICALITY AND FIRM QUALITY
}

\author{
Lisa B. Kahn \\ Erika McEntarfer \\ Working Paper 20698 \\ http://www.nber.org/papers/w20698 \\ NATIONAL BUREAU OF ECONOMIC RESEARCH \\ 1050 Massachusetts Avenue \\ Cambridge, MA 02138 \\ November 2014
}

The research program of the Center for Economic Studies (CES) produces a wide range of economic analyses to improve the statistical programs of the U.S. Census Bureau. Many of these analyses take the form of CES research papers. These papers have not undergone the review accorded Census Bureau publications and no endorsement should be inferred. Any opinions and conclusions expressed herein are those of the author(s) and do not necessarily represent the views of the U.S. Census Bureau or its staff. All results have been reviewed to ensure that no confidential information is disclosed. Republication in whole or part must be cleared with the authors. We are grateful to Jason Abaluck, David Atkin, David Berger, Judy Chevalier, Florian Ederer, Chris Foote, John Haltiwanger, Larry Katz, Fabian Lange, Alina Lerman, Giuseppe Moscarini, Peter Schott, Jim Spletzer, Till von Wachter and seminar participants at the AEA 2013 meetings, Cornell, CUNY, Federal Reserve Banks of Atlanta, St. Louis, and NYC, McGill, NBER Labor Studies, RPI, Stanford, Society of Labor Economics 2013 Meetings, Stavanger-Bergen Workshop, UC Santa Barbara, the University of Delaware, the University of Utah, and Yale for helpful comments. We especially thank John Abowd and Kevin McKinney for providing us with some data elements. A previous version of this paper was entitled "Worker Flows over the Business Cycle: the Role of Firm Quality" (2012). The views expressed herein are those of the authors and do not necessarily reflect the views of the National Bureau of Economic Research.

NBER working papers are circulated for discussion and comment purposes. They have not been peerreviewed or been subject to the review by the NBER Board of Directors that accompanies official NBER publications.

(C) 2014 by Lisa B. Kahn and Erika McEntarfer. All rights reserved. Short sections of text, not to exceed two paragraphs, may be quoted without explicit permission provided that full credit, including $(\mathrm{C}$ notice, is given to the source. 
Employment Cyclicality and Firm Quality

Lisa B. Kahn and Erika McEntarfer

NBER Working Paper No. 20698

November 2014, Revised June 2015

JEL No. E24,E32,J23,J3,J63

\begin{abstract}
Who fares worse in an economic downturn, low- or high-paying firms? Different answers to this question imply very different consequences for the costs of recessions. Using U.S. employer-employee data, we find that employment growth at low-paying firms is less cyclically sensitive. High-paying firms grow more quickly in booms and shrink more quickly in busts. We show that while during recessions separations fall in both high-paying and low-paying firms, the decline is stronger among low-paying firms. This is particularly true for separations that are likely voluntary. Our findings thus suggest that downturns hinder upward progression of workers toward higher paying firms - the job ladder partially collapses. Workers at the lowest paying firms are $20 \%$ less likely to advance in firm quality (as measured by average pay in a firm) in a bust compared to a boom. Furthermore, workers that join firms in busts compared to booms will on average advance only half as far up the job ladder within the first year, due to both an increased likelihood of matching to a lower paying firm and a reduced probability of moving up once matched. Thus our findings can account for some of the lasting negative impacts on workers forced to search for a job in a downturn, such as displaced workers and recent college graduates. For example, differential sorting and lack of upward mobility can account for roughly a third of the initial earnings impacts of graduating into a large downturn.
\end{abstract}

Lisa B. Kahn

Yale University

School of Management

P. O. Box 208200

New Haven, CT 06520

and NBER

lisa.kahn@yale.edu

Erika McEntarfer

U.S. Census Bureau

Center for Economic Studies

4600 Silver Hill Road

ACSD HQ-5K179

Washington, DC 20233

erika.mcentarfer@census.gov 


\section{Introduction}

Worker sorting across firms has long been thought to play a central role in labor market efficiency. Despite frictions that can inhibit this sorting process, such as search costs or imperfect learning, workers are thought to gradually move towards jobs of better overall- or match-specific quality. ${ }^{1}$ At the same time, recessions may impede worker sorting. Several papers have noted that worker churn and job-to-job mobility declined during recent recessions and that this decline was particularly severe during the Great Recession. ${ }^{2}$ This suggests that a worker's ability to move on from poor job matches or bad jobs is curtailed in times of high unemployment. A natural question, then, is in what types of jobs are workers - at least temporarily - saddled? If the business cycle has differential impacts on jobs or firms of varying quality, the consequences of reduced mobility could be very different. In this paper, we ask who fares worse in an economic downturn, low- or high-paying firms?

The classic Schumpeter (1939) cleansing effect posits that in recessions resources are reallocated to more productive firms, since, after a negative productivity shock, the least productive endeavors are no longer worthwhile. ${ }^{3}$ Because productivity and pay are typically positively correlated (see for example Serafinelli 2012), cleansing predicts that in recessions workers flow to high-paying firms. However, there are also reasons to expect employment to contract by relatively more among high-paying firms during recessions. For example, the notion of a job ladder suggests that workers tend to flow from bad jobs to good, i.e., from low- to high-paying jobs (Burdett and Mortensen 1998). If during recessions higher paying firms choose not to expand, then lower paying firms might find it easier to hold on to productive employees and thus shrink by relatively less than high-paying firms. ${ }^{4}$ It is also possible that high-paying firms produce goods for whom demand is more sensitive to the business cycle, maybe because they tend to produce goods that are more highly priced. ${ }^{5}$ Empirically, it is therefore an open question whether the job ladder effect or differential product market cyclicality will outweigh any Schumpeterian cleansing. If so, then during recessions, employment in low-paying firms would decline less rapidly than that in high

\footnotetext{
${ }^{1}$ This idea goes at least as far back as the canonical work of Jovanovic (1979); for empirical work on job mobility see Farber's 1999 survey.

${ }^{2}$ See in particular Lazear and Spletzer (2012), Hyatt and McEntarfer (2012a).

${ }^{3}$ Many theoretical papers seek to explain this phenomenon by exploiting a friction that inhibits resources from being allocated optimally. Recessions can produce large enough shocks to overcome any frictions inhibiting optimal reallocation. See for example Hall (1991), Mortensen and Pissarides (1994), Caballero and Hammour $(1994,1996)$ and Gomes, Greenwood and Rebelo (2001).

${ }^{4}$ Moscarini and Postel-Vinay (2013) write down a dynamic Burdett and Mortensen-style search model with a job ladder with exactly this implication, that in a downturn firms at the bottom of the job ladder fare relatively better since their workers are less likely to be poached away by firms at higher rungs.

${ }^{5}$ For example, Bils and Klenow (1998) show that consumer demand for luxury goods is more cyclically sensitive than for other products such as non-durables. The cyclical upgrading literature (Okun 1973, Bils and McLaughlin 2001) shows that jobs in high-paying industries (such as durable goods manufacturing) are more sensitive to the business cycle than jobs in low-paying industries (such as non-durable goods manufacturing), likely because products in these industries have more cyclically sensitive demand. This implies that opportunities to move into these jobs become relatively less prevalent in contractions.
} 
paying firms.

In this paper we investigate the employment effects of the business cycle across highand low-paying firms. We use data from the Longitudinal Employer Household Dynamics (LEHD) program, a U.S. employer-employee matched database, from 1998 to 2011. We first show that employment growth at low-paying firms is less sensitive to the business cycle, as measured by the state unemployment rate, than that at higher paying firms. This is important because it implies that the quality of jobs erodes in a downturn. We next provide evidence that the growth rate effect is likely driven by a partial collapse of movement up the job ladder in a bust, as opposed to differences in product market cyclicality and other possible factors. This implies that low-paying firms fare relatively better in a downturn because workers who would like to move on to better opportunities get stuck there. We estimate that movement up the job ladder is $20 \%$ slower for those working at the lowestpaying firms in a large bust, compared to a boom. We also estimate that the distribution of new job matches shifts towards these lower-paying firms in a downturn. The combination of a worse initial match and a reduced likelihood of upgrading implies that new job matchers are particularly scarred by recessions. We estimate that firm quality a year after matching, as measured by average firm pay, is $2.6 \%$ lower for those matching in a large recession compared to a boom. Thus the dynamics presented in this paper have important implications for the literature on the long-lasting effects of recessions on workers, which tends to find that those forced to search for jobs in a downturn, e.g., recent college graduates and displaced workers, are particularly damaged.

The growth rate result is surprising, since it is inconsistent with Schumpeterian cleansing. However it does line up with a small, recent body of work examining employment growth rates over the business cycle as a function of firm size. Moscarini and Postel-Vinay (2012) show in a number of countries including the U.S. that differential growth rates of small-, compared to large-, firms are positively related to the unemployment rate. ${ }^{6}$ This recent literature thus supports the notion that low-quality firms (small or low-paying) are somewhat sheltered by the business cycle, but has so far been unable to empirically pinpoint the underlying mechanisms. We devote the bulk of this paper to disentangling mechanisms, examining the differential impact of the business cycle on the components driving growth rates: hires and separations as well as proxies for voluntary and involuntary separations. We then quantify what these effects imply for workers careers. This paper thus generates a number of new empirical relationships that enable us to learn a great deal about firm dynamics over the business cycle.

\footnotetext{
${ }^{6}$ Also, Fort, Haltiwanger, Jarmin and Miranda (2013) analyze firm growth over the business cycle as a function of firm age and size, using U.S. data. They find that small, young, firms typically fare relatively better in cyclical contractions, although this relationship reversed in the 2007-09 recession. The recent work on firm size is at odds with an older literature, interested in establishing whether small firms face credit constraints and whether these are exacerbated in recessions. The literature had been inconclusive on this question but tended to find empirical support for a greater sensitivity to credit constraints among small firms. See for example Gertler and Gilchrist (1994), Chari, Christiano and Kehoe (2007), and Sharpe (2004).
} 
Net growth in a given quarter equals hires minus separations in that quarter. It is well known that both hires and separations decline during periods of high unemployment, and we show that this holds across all firms. However, we find that separations decline by more in lower paying firms than higher paying firms. This relative reduction in worker exits from low-paying firms accounts for their growth rate advantage. In addition, we find that the relative difference in separations is driven primarily by separations that appear voluntary on the part of workers (separations where the worker moves directly to another employer, rather than facing a period of time with no earnings). This finding is consistent with a partial collapse of the job ladder during downturns: low-paying firms grow relative to high-paying firms because workers who would ordinarily try to move on to better opportunities get stuck.

We do find, in addition, that firm behavior regarding layoffs plays a small role: in downturns higher-paying firms have small increases in separations that look like layoffs (where the worker moves to non-employment for some period of time), while low-paying firms do not. High-paying firms could face a greater need to lay off workers because demand for their products is more cyclically sensitive or because they had an easier time hiring workers during the preceding boom (being at the top of the job ladder) and now have become too large for production in a downturn. We test for the former by measuring whether revenues are differentially cyclical across high- and low-paying firms and do not find evidence of such an effect, though our test is imperfect since we can only obtain revenue data for publicly traded firms. We also find no evidence that high-paying firms suffer more from downward earnings rigidities, and therefore would have to layoff workers in tough times rather than cutting pay.

We view this body of results as being most consistent with a job ladder model where workers tend to use jobs at low-paying firms as stepping stones to better opportunities elsewhere. In an economic downturn those opportunities do not present themselves and workers are forced to stay put. Firms higher up on the job ladder will naturally experience this impact of a downturn less, because workers are more likely to see those jobs as final destinations, regardless of economic conditions. In particular, the Moscarini and PostelVinay (2013) poaching model predicts this set of findings. In their model, firms at the top of the job ladder poach workers away from firms at lower rungs, enabling them to grow in a boom. In a bust, they stop poaching because they do not need to produce at the same scale (and may indeed need to trim the fat off their existing workforce), enabling firms at lower rungs to retain their workers. This results in more cyclically sensitive employment at high-paying firms, while low-paying firms fare relatively better in a bust. ${ }^{7}$

Our results are very much in the spirit of Barlevy (2002) who shows that the decline

\footnotetext{
${ }^{7}$ In a recent paper, Haltiwanger, Hyatt and McEntarfer (2014) use the LEHD to measure the cyclicality of poaching across large and small firms. Counterintuitively, they do not find evidence that large firms poach from small firms, on net. However, motivated by our findings in this paper, they provide additional results categorizing firms by pay (as we do), rather than by size. Here they do find strongly pro-cyclical net employment reallocation of workers from low- to high-paying firms, consistent with our results.
} 
in job-to-job transitions seen in recessions has a quantitatively important negative effect on match quality, terming this the "sullying effect" of recessions. 8 We find that workers at low-paying firms suffer more from this decline in voluntary mobility, implying a further sullying effect of recessions: workers get stuck in worse overall quality (lower paying) jobs. Our estimates imply that in a large recession, workers in the lowest paying firms are $20 \%$ less likely to upgrade to a better firm in a large recession, compared to a boom.

Finally, our results have important implications for the long-lasting consequences of recessions on workers. A growing body of evidence suggests that recessions have vastly different impacts on workers in the long run, depending on what stage of their career the recession hits them in. First, labor market conditions at the beginning of a worker's career have long-lasting scarring effects (Kahn 2010, Oreopoulos, von Wachter and Heisz 2012, Altonji, Kahn, and Speer 2014). Second, the consequences of job displacement have been shown to be much larger when displacement occurs in a recession (Davis and von Wachter 2011). It therefore seems that being forced to search and match during an economic downturn can be incredibly damaging to a worker's career. We conclude the paper with some evidence on this dimension. We show that workers matching in a large recession are both more likely to match to a low-paying firm, and, one year later, less likely to have upgraded to a better firm. Therefore, a year after matching, a worker is in a firm that pays $2.6 \%$ less, on average, when matching in a bust compared to a boom. The firm dynamics discovered in this paper can thus account for roughly a third of the initial earnings losses experiences by workers graduating into a large recession, and much of the persistence of earnings losses over the early years of a career.

The remainder of the paper proceeds as follows. Section 2 describes the data, while section 3 details our methodology. Section 4 presents our core regression results on net and gross worker flows. Section 5 provides a discussion of the results, and tests for the underlying mechanisms. Section 6 shows how firm upgrading and the careers of new matchers are impacted by the mechanisms uncovered in the previous sections. Section 7 concludes.

\section{Data}

We analyze employment changes within firms and over the business cycle using data from the U.S. Census Bureau's Longitudinal Employer-Household Dynamics program (LEHD). The LEHD maintains a variety of survey and administrative data from several state and federal agencies. For this paper, we chiefly use state unemployment insurance (UI) wage records and the Quarterly Census of Employment and Wages (QCEW) data. Both UI and QCEW data are available for states in partnership with the LEHD program, currently all 50 states and the District of Columbia. A thorough discussion of the LEHD data is provided

\footnotetext{
${ }^{8}$ See also Bowlus (1993) and Davis, Haltiwanger, and Schuh (1996) for empirical evidence on the decline in match quality in recessions.
} 
in Abowd et al. (2009); a brief description follows.

State-level unemployment insurance (UI) data contain quarterly earnings for employees covered by state unemployment insurance systems, over $96 \%$ of private sector employment. A firm, as defined in this analysis, is a collection of workers who share a common unemployment insurance system identifier (SEIN). Individual wage records can be linked across quarters to create individual work histories, worker flows, and earnings dynamics. The firm identifier on the UI records is used to link to information on the firm available in the QCEW data (we principally use employment size and industry measured with the North American Industry Classification System, hereafter NAICS). Worker demographics, namely sex and date of birth, are available from links to the Census administrative and survey data. For this paper we restrict attention to the 34 states that have UI and QCEW data for every quarter of our sample period 1998:Q1-2011:Q4. This sample period was chosen to maximize the number of states for which a balanced panel of data exists over a reasonably long time period.

These data are advantageous in that they allow us to observe both gross and net worker flows for a substantial fraction of firms in the U.S. labor market. Furthermore, we can create a rich set of firm characteristics to measure employer quality. Finally, the time period over which we can exploit a balanced panel consisting of a large number of states allows us to capture both the 2001 and 2007-09 recessions. In this section we discuss the data choices made for our primary specifications. We include a lengthy discussion about robustness to other choices in section 4.

Our exercise in this paper is to analyze how firms of different qualities are impacted by the business cycle. Our measure of quality is based on average pay in the firm. Since one goal of this paper is to better understand the experiences of workers in recessions, we would ultimately like our quality measure to correlate with properties of a desirable job. Obviously pay is an important dimension of worker satisfaction. Furthermore, firms that can pay higher wages are likely more productive. Serafinelli (2012), for example, presents evidence using detailed administrative data in Italy that high paying firms are indeed more productive. We construct time-invariant pay measures by taking average wage within a firm over our entire sample period (1998-2011). This avoids the well-known reclassification bias problem (for example, that a firm is reclassified into a higher pay bin as the economy grows; see Moscarini Postel-Vinay (2012)), though our results are robust to other measures. ${ }^{9}$

Figure 1 shows an employment-weighted kernel density of firm-level average monthly earnings (for employees who work an entire quarter, in 2008 dollars). ${ }^{10}$ This distribution has a long right tail and to avoid potential data disclosure issues, we cap earnings at $\$ 12,000$.

\footnotetext{
${ }^{9}$ In particular, we have experimented with using a two-quarter moving average as in Fort et al. (2013). Our results are also robust to categorizing based on average pay at the establishment, rather than firm (the LEHD imputes workers in a close geographic region to the same establishment within an SEIN).

${ }^{10}$ Monthly pay is defined as quarterly pay divided by 3 . We ensure employees work the entire quarter by restricting to employees who have non-zero earnings from the firm in both the preceding and subsequent quarters.
} 
As can be seen, we have substantial variation across firms over this time period. Average pay in this sample is $\$ 3,815 /$ month, and has a standard deviation of $\$ 66,244$.

For the main analysis, we take advantage of prototype data on job-to-job flows developed from the LEHD by Hyatt and McEntarfer (2012b). ${ }^{11}$ This dataset restricts attention to primary jobs only (the job that pays most in a given quarter for a given worker). One disadvantage of the LEHD is that the data are only reported quarterly. This restriction helps avoid some of the noise generated by this limited periodicity, but we discuss robustness in section 4 .

To categorize firms, we divide them into employment-weighted quintiles, based on the average pay measure using state-industry-specific cut points (measured at the two-digit NAICS level). Our categories thus define firms as high- or low-paying relative to other firms in the same state and industry. Workers in the lowest paying quintile earn on average $\$ 1,842 /$ month, while workers in the highest paying quintile earn on average $\$ 6,665 /$ month (see table 1 discussed below).

We subsequently analyze the impact of the unemployment rate on growth rates as a function of firm quality, measured by the pay quintiles. We have a number of reasons for making these pay quintiles state-industry specific. First, our definitions are not sensitive to different costs-of-living across states. Second, firms may have different average labor bills for reasons unrelated to the quality of the job. For example, a greater reliance on part-time workers would lower the overall labor bill (we cannot measure hours); a greater reliance on sub-contractors for particular roles would shift the pay distribution within a firm (we cannot measure occupation); a different mix of base pay, benefits, bonuses, tips, could also alter the level and distribution of pay within a firm. Third, different industries exploit different technologies, some of which may be more correlated with aggregate economic shocks than others. Making our cutpoints industry-specific should at least help hold constant these factors. Finally, we identify the impact of the business cycle using local labor market conditions, as measured by the state unemployment rate. This measure is likely less relevant for traded sectors and will vary across states with different natural rates of unemployment. The fact that our cutpoints are comparisons across firms within state and industry helps here as well.

The key dependent variables in this paper are net employment growth rates as well as gross flow rates. To calculate these rates, we aggregate our firm-level data to the state-yearquarter-industry-wage quintile category, by summing employment and worker flows in each cell. $^{12}$ This level of aggregation allows us to control for industry, while still enabling us to

\footnotetext{
${ }^{11}$ These data link primary jobs across quarters, using the timing of hires and separations to infer which worker moves are job-to-job moves (with little-to-no time in non-employment) versus moves to and from longer spells of unemployment. These data are also used in Hyatt and McEntarfer (2012a), who document aggregate patterns in worker flows over the last 15 years and compare changes in earnings for different types of moves, and Haltiwanger, Hyatt, and McEntarfer (2014), who measure the extent of poaching behavior by large firms away from small firms.

${ }^{12}$ We aggregate to the three-digit NAICS industry level here so that we can both control for two-digit
} 
capture employment dynamics driven from firm births and deaths. ${ }^{13}$

Specifically, the quarterly growth rate in a given quarter, $t$, for a firm pay type, $q$, is defined in equation 1, where $A$ is the number of hires in a given quarter, $S$ is the number of separations from the firm, and $E$ is total employment over the quarter.

$$
\text { growth } \operatorname{rate}_{t q}=\frac{\sum_{f=1}^{F_{q}}\left(A_{t f}-S_{t f}\right)}{\sum_{f=1}^{F_{q}} E_{t f}}
$$

The growth rate is the net employment change $(A-S)$ among all firms, $f$, of type $q$ (firms are indexed 1 to $F_{q}$ ) divided by employment over the quarter, $t$, among these firms.

We define the hire (separation) rate as total hires (separations) divided by total employment in a given cell. ${ }^{14}$ Thus, by definition the growth rate equals the hire rate minus the separation rate.

We further decompose both separations and hires into those directly to/from employment and those to/from non-employment. A separation is categorized as a move directly to another employer if the worker has pay from another employer in the same quarter as the separation or the quarter immediately following. Because our data only come at a quarterly frequency, a worker must have at least a full quarter without earnings to be categorized as a mover to non-employment. See Hyatt and McEntarfer (2012b) for more detail. We discuss the likely direction of this bias in section 5. Information on gross hires and separations, as well as decompositions across source or destination of the worker are not available in most data sets, even those containing measures of net employment growth, and herein lies much of our contribution.

Table 1 presents employment-weighted summary statistics by firm category for our rates of interest. Thus the 5 categories in table 1 contain a roughly equal number of workers. Throughout our analysis, we weight by employment so that our results can be interpreted as impacting the average worker rather than the average firm. ${ }^{15}$ Again, the unit of observation

industry fixed effects, and experiment with other controls at a more disaggregated level.

${ }^{13}$ While in principle, we could conduct our analysis at the individual firm level, that would produce growth, hire and separations rates that are quite a bit noisier. These rates may not be defined or may be misleadingly large in the period in which a firm starts or closes and outliers can be generated by seasonal employers or non-reporting events (or in principle mergers and acquisitions, though the LEHD use an algorithm to exclude these events). At the individual firm level, these outliers create problems for our estimation, so we prefer the slightly aggregated analysis presented here. This aggregation is particularly important given an LEHD data limitation: that it is difficult to link firms consistently over time due to periodically changing SEIN's. Though again, the LEHD have algorithms that avoid misclassifying workers as moving firms when SEIN changes. See Abowd et al. (2009) for more detail on these algorithms.

${ }^{14}$ Temporary layoffs and recalls will be considered separations and hires if the worker earns no money from the firm for at least a full quarter.

${ }^{15}$ This in a more representative sample, give the large left tail of small firms. See for example Haltiwanger et al. (2013). 
is a date-industry-state-pay quintile cell. Growth rates are fairly similar across pay quintiles, ranging from 0.0014 to $0.003 .^{16}$

Hire and separation rates are highly correlated within firm category, reflecting the fact that most hiring serves to replace workers who have separated, but rates vary widely across firm category. For example, gross hire and separation rates in the lowest pay quintile are, on average, over double the rates in the highest pay quintile. Across our whole sample period and for all types of firms, separation rates are roughly evenly split between separations to employment and non-employment. Hires are also roughly evenly split across those from employment and those from non-employment, except that at lower paying firms workers are relatively more likely to be hired from non-employment, while the opposite is true at higher paying firms. Jobs at higher paying firms could be more difficult to obtain, consistent with their more desirable position on the job ladder, so such firms tend to hire from a higher quality pool of workers, the employed.

Table 1 also shows the distribution of workers in a given pay quintile across other measures of firm quality, churn and size. Excess churn is a measure of how many workers moved in and out of the firm for a given net employment change. ${ }^{17}$ Campbell et al. (2005) show that high churn is associated with lower productivity and lower survival rates for a select set of industries. We place firms into quintiles based on their average churn over the sample period. From column 1 of table 1, about a third of firms in the lowest pay quintile are in the highest churn quintile, while only a tenth are in the lowest churn quintile. These ratios are almost exactly reversed in column 5, the highest pay quintile. This illustrates the strong negative correlation between pay and churn.

Firm size is defined as the number of employees in the SEIN on the 12th day of the first month of the quarter, averaged over the life of the SEIN. ${ }^{18}$ Larger firms have been shown to have higher pay, better working conditions, a greater degree of benefits provision, increased productivity, and increased probability of firm survival (Brown and Medoff 1989, Hurst and Pugsley 2011). In our data, the lowest paying firms are predominantly found in either the smallest (less than 20 ) or largest $(500+)$ size categories. The majority of higher paying firms

\footnotetext{
${ }^{16}$ Based on our categorization, high-paying firms have double the growth rate of the other quintiles. One might have expected lower paying firms to grow more quickly because of positive correlations between pay, size, and age. Haltiwanger, Jarmin and Miranda (2013) show that small firms grow faster than large firms, but this is driven by the fact that small firms are also younger. By generating quintile cutpoints that are state-industry-specific, we make firms across categories much more similar to each other. For example, while a third of low paying firms (based on our categorization) are small, another third are very large. Overall the lowest paying firms (unconditional on state and industry) are much more likely to be small and are also the fastest growing.

${ }^{17}$ Specifically, we define the churn rate as $\frac{A_{t f}+S_{t f}-\left|A_{t f}-S_{t f}\right|}{E_{t f}}$, a definition which is now standard in the literature (see Burgess, Lane, \& Stevens (2000).

${ }^{18}$ Both Fort et al. (2013) and Moscarini Postel-Vinay (2012) use firm size data from the BDS, which contains information on both establishment-level employment and national employment. Our measure of firm size is correlated with the national size of the firm (0.75) but is not an exact match, more closely approximating the size of the firm in the state, the same level at which we are classifying firms into pay quintiles.
} 
are in firms with at least 500 employees.

\section{Methodology}

In order to understand the differential impact of the unemployment rate on growth, hire, and separation rates across firm pay quintiles, we estimate regressions of the form specified in equation 2.

(2) rate $_{s I t q}=\alpha_{0}+\alpha_{1} s t \_u n e m p_{s t}+W_{q} \alpha_{2}+\left[s t \_u n e m p_{s t} * W_{q}\right] \alpha_{3}+f(t)+I^{\text {industry }}+I^{\text {state }}+\varepsilon_{s I t q}$

We regress rate $_{\text {sItq }}$, a growth, separation, or hire rate among firms of quality, $q$, in state, $s$, in industry (three-digit NAICS), $I$, in time period, $t$, on the state unemployment rate in quarter $t\left(s t \_\right.$unemp $\left.p_{s t}\right)$, a vector of firm quality indicators $\left(W_{q}\right)$ corresponding to pay quintiles, and their interactions. The coefficient, $\alpha_{1}$, yields the impact of a 1 percentage point (ppt) increase in the state unemployment rate on rate $_{s I t q}$ for the omitted firm quality category, the lowest pay bucket. The vector of interaction terms, $\alpha_{3}$, indicates whether the impact of st_unemp is different for higher pay buckets. The main effects of firm quality $\left(W_{q}\right)$ and the state ( $\left.I^{\text {state }}\right)$ and industry fixed effects ( $I^{\text {industry }}$, at the two-digit NAICS level) control for level differences in rate $_{s I t q}$ across these observables (for example, some industries may on average be shrinking and others growing). We also control for the average distribution of size and churn within a pay bucket. ${ }^{19}$

We include flexible controls for the time period, $f(t)$, in two forms: First, we control for quarter fixed effects and a linear time trend. These allow us to control for seasonality and secular changes over this time period (for example, the marked decline in churn during the 2000s), while still exploiting time-series variation in economic conditions at both the national and state levels. However, since we only have a short time period, we would like to ensure that our results are not driven by spurious correlations due to anomalies that coincided with business cycle movements. Therefore, in an alternative specification, we control for date fixed effects, absorbing all variation in the national time series and identifying purely off of cross-sectional variation in economic conditions.

We weight observations by employment and cluster our standard errors by state. Our key explanatory variable, the state-specific unemployment rate, varies at the state-level and over time, but is likely serially correlated within state. ${ }^{20}$

We interpret equation 2 as informing how worker flows vary with local economic condi-

\footnotetext{
${ }^{19}$ Given both variables are highly correlated with firm pay, it is useful to know whether either size or churn are the underlying drivers of the dynamics reported in the paper, or whether these dynamics exist within size and churn. We can understand this to the extent that there is variation within pay bucket in these variables. In practice results are nearly identical with and without these controls, suggesting differences in pay across firms is the primary driver of our results, not differences in size or churn.

${ }^{20}$ We have also clustered at the state-date-firm quality level and obtained very similar results in terms of statistical significance.
} 
tions and whether they vary differentially across pay quintiles. We have chosen this specification to rule out a number of alternative channels through which the unemployment rate might be correlated with worker flow measures. First, controlling for state fixed effects and flexible controls for time period rule out that general differences across locations or time periods drive our results and we instead pick up the relationship between idiosyncratic shocks to the unemployment rate and worker flows. Second, and as mentioned above, our $W_{q}$ classification does not vary over time. Thus we will not have differential representation of firms across quintiles that varies systematically with the unemployment rate. Third, the sItq-cells are small enough so that we do not worry about reverse causality - no given cell makes up enough of a state-quarter economy to drive the unemployment rate.

Finally, one might worry that labor market shocks were mis-measured by the state unemployment rate, and especially if this was differential across firm type. For example, for firms producing non-traded goods, the local unemployment rate is likely highly correlated with whether the firm experiences a shock, while for firms producing traded goods, the local unemployment rate may be less indicative. First, we point out that in some specifications we exploit both local and national variation in economic conditions, and these will be most relevant for firms producing traded goods. Second, this kind of measurement error in economic conditions will bias $\alpha_{3}$ downward in magnitude, especially for pay buckets with a higher share of firms producing traded goods. It is well known in the trade literature that exporting firms are higher paying. ${ }^{21}$ Thus this should be a larger problem for higher pay buckets, biasing us against our finding that growth rates at higher paying firms are more sensitive to the business cycle.

It is therefore unlikely that equation 2 suffers from reverse causality, measurement error, or systematic differences across firm categories that are correlated with the unemployment rate.

\section{Regression Results on Growth, Hire, and Separation Rates}

\subsection{Growth Rate}

\section{Time Series}

Figure 2 gives a a general sense of the time series relationships among economic conditions and growth across firm quality. The left panel plots growth rates for the lowest and highest

\footnotetext{
${ }^{21}$ See Bernard, Jensen, Redding, and Schott (2007) for a survey. They cite a wealth of evidence documenting that exporters tend to be larger, more productive, more skill- and capital-intensive, and higher paying, relative to non-exporters.
} 
pay quintiles. ${ }^{22}$ They are quite noisy, but show that growth rates are similar in magnitude for low- and high-paying firms and that they trend together and opposite the unemployment rate (dashed line). Also one can see that the light line (highest pay quintile) has larger fluctuations than the dark line (lowest pay quintile); the light line falls lower than the dark line in downturns and rises above it in booms.

The right panel illustrates the differences more clearly, plotting a differential rate where we subtract the growth rate at the highest pay quintile from that at the lowest in a given quarter. This is similar to the large-small firm comparison in Moscarini and Postel-Vinay (2012). It shows that the differential rate very closely tracks the national unemployment rate. That is, when unemployment is high, low-paying firms grow relative to high-paying firms, while when unemployment is low, low-paying firms shrink relative to high-paying firms. Note these effects are symmetric across booms and busts.

\section{Main Regression Results}

The time series evidence presented in figure 2 is suggestive, however with such a short panel of data, we cannot perform any sort of reliable statistical inference based solely on this time series. We now turn to a regression framework where we exploit cross-sectional variation in unemployment rates across our 34 states and 56 quarters. Results are reported in table 2. The dependent variable is the growth rate (net change in employment divided by average employment over the quarter) in the state-date-industry-wage quintile. We focus first on panel A, which reports the point estimates and standard errors from equation 2. The specification in column I controls for time period with quarter fixed effects and a time trend, while column II instead controls for date fixed effects. The remaining columns show robustness to alternative specifications and are discussed below. Results are extremely similar across columns I and II, and we tend to focus on column II since the date fixed effects absorb any coincidental trends that are correlated with the unemployment rate.

From column II, the main effect of the unemployment rate, shown in the top row, is negative, though very small in magnitude (0.00019) and not statistically significant. This coefficient can be interpreted as the impact of the unemployment rate on the growth rate for the lowest pay quintile - the omitted category in each regression. This regression suggests, then, that the employment growth rate at low paying firms is acyclical. The interaction terms show the differential impact of the state unemployment rate on the growth rate at higher paying firms. They are all negative and statistically significant at the $1 \%$ level. This means the state unemployment rate has a more negative impact on the growth rate at higher paying firms. For example, a coefficient of -0.0011 (with a standard error of 0.00009) among the highest paying firms, indicates that for each percentage point increase in the unemployment rate, these firms shrink by 0.0011 more than the tiny effect seen in

\footnotetext{
${ }^{22}$ All lines have been detrended using a Hodrick-Prescott filter (with a smoothing parameter of 1600 ), and seasonally adjusted by residualizing on quarter dummies. Therefore the levels are not that meaningful.
} 
the lowest paying firms. Multiplying this coefficient by 6 yields the predicted impact of the Great Recession on the growth rate, $-0.006 .{ }^{23}$ This effect is quite large considering the mean growth rate for this group was roughly 0.003. Coefficients are fairly similar for the 3rd through 5th wage quintiles, while smaller in magnitude for the 2nd quintile but still significantly different than the impact on the lowest paying firms.

Because firm types differ in their baseline growth rates (for example, the growth rate in the highest paying firms is nearly double that in the lowest paying firms), and to help interpret the magnitudes of our effects, we convert our estimates to elasticities. Panel B reports the total impact of a $1 \%$ increase in the state unemployment rate on the growth rate at each firm-quality bucket (adding an interaction term to the main effect of the unemployment rate for higher paying firms). ${ }^{24}$ Again from column II, we find that in response to a $1 \%$ increase in the state unemployment rate, the growth rate among the lowest paying firms does not change while the growth rate for the highest paying firms declines by $1.8 \%$. Elasticities are substantially larger in magnitude for the 2nd-4th pay quintiles, where growth rates decline by $2-3.5 \%$.

\section{Robustness}

We explore results from a number of different specifications and samples. In column III, we estimate separate regressions for each pay quintile and report the coefficient on the state unemployment rate. ${ }^{25}$ This implicitly allows the impact of all of our control variables to vary by pay quintile. These might be important if, for example, there exist differences in growth rates across industry-quintile or state-quintile, and if quintiles vary in their seasonality or in the impact of national trends. ${ }^{26}$

Column IV redefines our quintile cutpoints at an aggregated level, rather than at the state-industry level. The set of firms in each pay quintile may be different when comparing within the state-industry than the placement of firms in the overall pay distribution. We discussed at length in section 2 why we prefer the relative comparison. However, we also provide the absolute comparison to show that our results have implications for the economy as a whole, not simply for dynamics within these more narrow comparisons.

Column V excludes firms with less than 50 employees and redefines quintile cutpoints so that employment in the remaining sample is evenly divided among them. This is important for several reasons because small firms are also likely to be low-paying. First, small firms may experience less of an impact on their growth rates because of a divisibility problem: in very

\footnotetext{
${ }^{23}$ The national unemployment rate rose from 4.2 in 2006:Q4 to a peak of 10.4 in 2010:Q1.

${ }^{24}$ To obtain these elasticities we add $\alpha_{1}$ to the relevant interaction term in $\alpha_{3}$ (or nothing in the case of the lowest quintile), multiply and divide by the quintile-specific averages for the state unemployment rate and the growth rate (respectively) reported in table 1.

${ }^{25}$ The coefficients in this column thus reflect the total impact of the unemployment rate on the growth rate, not a main effect and interactions.

${ }^{26}$ Though not reported, we have also experimented with controls for state- and industry-specific seasonality and obtained similar results.
} 
small firms, laying off a single worker would stop production and hiring a new worker would double production. Second, small firms provide fewer non-pecuniary benefits to workers, systematically biasing our pay measure, relative to the total value of the job. Third, small firms are known to be much more dynamic in terms of births and deaths. The fact that results are similar with and without small firms suggests that the differential impact of the unemployment rate on growth rates is similar across both intensive and extensive margins. It also helps with the problem that average pay is measured over different lengths of time across firms. New firms that only have pay measures for a short time period will be more sensitive to temporal factors impacting pay. Removing small firms clears out much of the noise that this would generate. ${ }^{27}$

Column VI categorizes firms by their fixed effect in a quarterly earnings regression, based on the Abowd-Kramarz-Margolis (1999) method (hereafter, AKM). ${ }^{28}$ Our primary firm quality definition does not distinguish between firms that are high-paying from firms that tend to employ highly-paid workers. The regression that generates firm fixed effects controls for worker fixed effects and time-varying controls. This allows us to pinpoint that our effect as applicable to high-paying firms. It also adjusts for the fact that pay is observed at different time periods for different firms, mentioned above.

Finally, column VII relaxes the exclusion of non-primary jobs, including all jobs. We can thus observe whether the dynamics hold for secondary jobs as well as primary jobs. ${ }^{29}$

As can be seen, results are remarkably similar across specification. Impacts on growth rates for the lowest paying firms are always smallest and usually close to zero, while impacts are larger in magnitude for higher paying firms. In all specifications the impact does plateau at the highest paying firms so that the starkest contrast comes from comparing the lowest and upper-middle firms. Elasticities are calculated using the sample-specific means and show that for most specifications, impacts at the highest paying firms are also smaller in magnitude, compared to the middle firms. When small firms are excluded (column V) and when we use AKM fixed effects (column VI) we do find cyclical growth rates for even the lowest paying firms. This is probably because these two specifications result in the categorizations among very similar groups. However, we still always see that the lower paying firms are less cyclical than higher-paying firms.

\section{Summary}

Thus from table 2, we conclude that growth rates at the lowest paying firms are less cyclically sensitive than those at higher-paying firms. These results have implications for the distribution of jobs over the business cycle, since low-paying firms grow relative to higher-

\footnotetext{
${ }^{27}$ Also, small businesses may manage differently than larger firms. For example, Hurst and Pugsley (2011) show that most small business owners intend to serve an existing customer base and do not intend to grow. This would imply less growth in booms and as a result possible less shrinkage in busts.

${ }^{28}$ We thank John and Abowd and Kevin McKinney for providing these fixed effects.

${ }^{29}$ For technical reasons, growth rates in this sample also more accurately capture firm births and deaths.
} 
paying firms in busts. To put a magnitude on that, we can take average monthly earnings in each type of firm, reported in table 1, and predict average pay in the economy based on the implied distribution of workers across firms. Starting from a point when workers are evenly distributed across the quintiles, the average worker is in a firm paying $\$ 3,815 /$ month. Our estimates imply that after the Great Recession, the average worker is in a firm paying $\$ 4 /$ month less. That means that worker pay should fall in a recession by nearly $0.1 \%$ simply because of these aggregate firm dynamics, and not including any impacts on individual worker pay. During the Great Recession, real gross domestic income fell by $3.8 \%$. Compared to this benchmark, the impact on the distribution of workers across firms is modest, but not unsubstantial. We show in section 6 that the impact of this pay drop is substantially larger for those employed by the lowest paying firms when a downturn begins.

\subsection{Hire and Separation Rates}

The regressions in table 2 show that growth rates at higher paying firms are more negatively impacted by the unemployment rate. We are the first to show these results as a function of firm pay. These are, however, quite consistent with work showing that small firms are less cyclically sensitive than large firms (Moscarini and Postel-Vinay 2012) because small firms are more likely to be low-paying. However, previous work could not decompose the growth rate effect into its components. This is important because it helps to distinguish the underlying mechanisms driving the growth rate effect. We provide the first such analysis in the subsequent sections.

By definition, the growth rate equals the gross hire rate minus the gross separation rate and we next analyze the impact of the unemployment rate on these two margins. First, to get a general sense of how these fluctuate differentially across firms over the business cycle, we plot the separation and hire rates for the lowest and highest pay quintiles, as well as the differential rates in figures $3 \mathrm{a}$ and $3 \mathrm{~b}$.

Looking first at separation rates in $3 \mathrm{a}$, we see very different patterns than in figure 2. First, in the left panel, the dark line (separation rates in the lowest pay quintile) clearly exhibits much bigger amplifications than the light line (the highest pay quintile). This is the opposite of what we saw in figure 2 and is much more pronounced here. Consistent with this, the differential separation rate (left panel) is procyclical. When the unemployment rate is

low, low-quality firms separate at greater rates than high-quality firms, while the opposite is true in times of high unemployment. These effects are again largely symmetric across booms and busts. Patterns for hire rates are similar, though the amplitudes in the left panel are more similar across low- and high-paying firms.

Table 3 summarizes key regression results, reporting the preferred growth rate estimates in column I (from column II of table 2), as well as the same specification for the separation rate (column II) and the hire rate (column III). Because of the way we defined the dependent 
variables, a coefficient for the hire rate minus that for the separation rate equals that for the growth rate. Appendix tables 1 and 2 contain the full set of specifications with all robustness checks.

Both separation and hire rates show quite similar patterns to each other, though like the figures, opposite patterns to the growth rate. From panel A, the main effect of the unemployment rate is negative and a similar magnitude for both hires and separations, while the interaction effects are positive and significant. That is, a higher unemployment rate is associated with reductions in both hires and separations. The magnitude of this effect is larger at the lowest paying firms, and somewhat offset at higher paying firms. ${ }^{30}$ The interaction terms increase with pay quintile, so the sharpest contrast is for the lowestand highest-pay quintiles, though the contrasts are stronger for separation rates than for hire rates. Our estimates imply that in the Great Recession, separation rates would have declined by 1.7 ppts at the lowest paying firms and by 0.25 ppts at the highest paying firms, while hire rates would have declined by 1.6 and 0.8 ppts, respectively.

Panel B reports elasticities, analogous to table 2. Converting to elasticities is particularly important here because the average separation and hire rates at the lowest paying firms is double that at the highest paying firms (from table 1), making the units difficult to compare. For example, it would be much easier for a firm to reduce its separation rate by a third of a ppt off a base of $20 \%$ than off a base of $10 \%$. For separation rates, the elasticities hold up to the patterns presented in panel A; elasticities at lower paying firms are larger than those at higher paying firms. In contrast, elasticities for hire rates are similar in magnitude across firm quintile. ${ }^{31}$

\subsection{Discussion}

Table 3 shows that while growth rates are less impacted by the business cycle at low paying firms, separation rates are more impacted and impacts on hire rates are roughly similar. This implies that the growth rate effect is driven by the separations margin. The lowest paying firms have a dramatic decline in worker exits in a downturn, which allows them to maintain their workforce in spite of a large reduction in hiring. Higher paying firms do not see such a decline in separations but they still have relatively large declines in hiring (in percent changes they see a fairly similar decline to lower paying firms).

\footnotetext{
${ }^{30}$ That separation rates decline in times of higher unemployment might be surprising given we expect firms to make more layoffs in a worse economy. However, this finding is consistent with a more-than-offsetting decline in voluntary quits (e.g., Shimer 2005, Hall 2005b).

${ }^{31}$ Results are again quite similar across specification. The general pattern that lower paying firms experience larger reductions in separation rates, compared to higher paying firms, holds robustly for both coefficients and elasticities. Impacts on hire rates are less consistent. The inclusion of date fixed effects does reduce the magnitude of the main effect (compare columns I and II in appendix tables 1 and 2), meaning that some of the overall effect is due to sensitivity to national economic conditions. Because the interaction effects remain constant across these specifications, we infer that the differential impacts across firms is primarily driven by local variation.
} 
Figure 4 illustrates this result. Here we plot the total impact of a one percentage point increase in the unemployment rate on growth (solid blue), hire (red line connected by dots), and separation (green line connected by plus signs) rates across firm pay quintile (ignore for the moment the dashed lines). ${ }^{32}$ The growth rate effect is close to zero for the lowest quintile, and exhibits a shallow decline (increase in magnitude) across higher quintiles, before leveling off at the highest quintiles. In contrast, the separation and hire rate impacts are large in magnitude and negative for the lowest wage quintile and steadily increase (decrease in magnitude) across higher quintiles. The separation rate effect is very close to zero for the highest paying firms. Thus, while net employment changes are more cyclical at high-paying firms, gross worker flows are more cyclical at low-paying firms.

The gap between the hire and separation and rate effects (which will add up to the growth rate effect) is largest among the highest paying firms - separation rates do not decline by as much as hire rates in a bust so high-paying firms shrink. In contrast, hires and separations decrease by roughly the same amount at the lowest paying firms, so net employment remains roughly constant. In boom times, low-paying firms have relatively more separations, with a commensurate increase in hires, resulting again in a constant size, while high-paying firms increase their hires by more than their increased separation rate, resulting in faster growth.

\section{Distinguishing among theories}

We have shown that employment growth rates at low-paying firms are less sensitive to the business cycle than those at high-paying firms. Furthermore, the employment advantage afforded low-paying firms in downturns is driven by a large reduction in worker separations, and exists despite a roughly equally large decline in hiring at these firms. Separations occur because of voluntary worker exits and layoffs. In downturns, the former decline while the latter increase. So it must be that either low-paying firms experience a larger reduction in voluntary quits, or lay off fewer workers when times are tough, or both. Which of these effects occur, and why?

As we noted in the introduction, there are several theoretical reasons why high- and lowpaying firms would be differentially impacted by the business cycle. First, Schumpeterian cleansing predicts that when a negative productivity shock renders the least productive endeavors no longer worthwhile, resources will be reallocated to more productive firms. Our finding that resources are reallocated from high- to low-paying firms, is inconsistent with Schumpeterian cleansing because of the typical positive correlation between pay and productivity.

Second, a temporary collapse of the job ladder, a la the Moscarini Postel-Vinay (2013) poaching model has several implications. In good times, firms at the top of the job ladder

\footnotetext{
${ }^{32}$ From table 3, we add the main effect of the unemployment rate (the impact for the lowest pay quintile) to the relevant interaction term.
} 
(for example, higher paying firms) can poach workers away from firms at the bottom (lowerpaying). As such, top firms become larger, while bottom firms have difficulty retaining workers. In a downturn, the top firms reduce their poaching efforts because the temporary decline in productivity means it is no longer optimal to operate on as large a scale. This model as four empirical implications that are relevant for our setting: (1) low-paying firms grow relative to high-paying firms in a downturn because a reduction of poaching by high-paying firms enables low-paying firms to retain their workforce; (2) low-paying firms experience a relative decline in voluntary quits in a downturn because high-paying firms poach them less often; (3) high-paying firms may increase layoffs in a downturn because the ease with which they hired workers in the boom rendered them too large for optimal production in a bust; (4) the decline in poaching behavior in a bust implies that high-paying firms will exhibit a relative decline in hires from other employers. We have already shown that (1) holds in our data. We provide the first empirical tests of the remaining predictions, below.

Third, firms may differ in how a recession impacts their profitability because of differential product demand cyclicality. In particular, high-paying firms may sell more expensive products. Bils and Klenow (1998) showed that luxury products have more cyclical demand. If there is a positive correlation between worker pay and prices then we might expect higher paying firms to be more sensitive to business cycle fluctuations. For example, consider an inexpensive chain restaurant and a five-star restaurant. The latter most likely pays their employees more and also might have more cyclical demand. This model also predicts that high-paying firms will have a relatively greater need to cut labor costs, perhaps via layoffs, but also has implications for revenue. Below, we test for differential product demand cyclicality by measuring the differential impact of the business cycle on revenue growth using Compustat data.

Fourth, for a given need to cut on the labor bill, firms may be differentially able to adjust without laying off workers. A long-standing literature (see for example Shimer (2004) or Hall (2005a) among many others) points to nominal wage rigidities as an explanation for larger employment fluctuations than fluctuations in other market fundamentals. The degree to which nominal wages are downwardly rigid remains a completely open empirical question with evidence on all sides (see Pissarides 2009 for a survey). Furthermore, to our knowledge no one has examined pay rigidity as a function of average firm pay. On the one hand, high-paying firms may pay a higher share of salaries in the form of bonuses, which are likely much easier to adjust. At the same time, low-paying firms likely pay more of their workforce on an hourly basis, so may have an easier time cutting take-home pay through hours reductions. ${ }^{33}$ If the latter holds and low-paying firms are relatively more able to adjust

\footnotetext{
${ }^{33}$ The queuing literature also suggests that high-paying firms will have more rigid pay, relative to lowpaying firms. High-quality firms post a high wage, which results in a long queue of workers who wish to work there, driven for example by an efficiency wage (Akerlof and Yellen 1985), imperfect information (Weiss 1980) or explicit personnel policies (Okun 1973). They would then find it easier to adjust the size of their workforce without adjusting wages. A corroborating piece of evidence comes from the cyclical upgrading
} 
worker pay downward, then we should again expect more layoffs from high-paying firms. We examine the differential probability of making nominal earnings cuts below.

\subsection{Poaching}

In this subsection we decompose separations and hires based on the destination or source, employment or non-employment, to test predictions 2-4 of the Moscarini-Postel-Vinay poaching model. Because of the periodicity of the LEHD, we can only define a move as to or from non-employment if the worker experienced a full quarter with no earnings. We discuss the likely impact of this limitation below. Still these measures are useful in giving some indication for why a move occurred. A separation where a worker moves directly to another job is more likely to have been voluntary than one where the worker had a complete quarter with no earnings. ${ }^{34}$ Furthermore, a hire that was directly from employment is more likely to be driven by poaching than a hire where the worker sat out of the labor market for at least a month.

Table 4 summarizes key regression results for this section, reporting the preferred growth rate estimates in column I (from column II of table 2), as well as the same specification for separation-to-employment and non-employment rates, and hire-from-employment and non-employment rates. Because of the way we defined the dependent variables, coefficients for the two separation (hire) rates will sum to the full separation (hire) rate effect in table 3, column II (III). Also, the sum of the two hire rate effects minus the sum of separation rate effects adds up to the growth rate effect. Appendix tables 3-6 contain the full set of specifications with all robustness checks.

The regression coefficients in panel A show that for separations to employment (column II), the lowest paying firms experience a large negative drop in response to an unemployment rate increase, significant at the $1 \%$ level. The positive interaction terms, show that this effect is offset somewhat at higher paying firms, mirroring the gross separation rate results from table 3, and most differences are significant at the $1 \%$ level. For example, impacts on the highest paying firms are three-quarters smaller in magnitude, than for the lowest-paying firms. Elasticities in panel B also mirror this result. ${ }^{35}$ This result is therefore consistent with prediction $\# 2$ from the poaching model, that low-paying firms experience a relatively larger decline in voluntary quits in a downturn.

The separations to non-employment results (column III) show that while the lowest

literature which finds that wages are more cyclical in low-paying industries (Bils and McLaughlin 2001). This would nicely explain why high-quality firms need not increase wages in expansions, however, is it less compelling for explaining why a firm would not lower wages in a contraction.

${ }^{34}$ Hyatt et al. (2014) find a high correlation between separations to non-employment in the LEHD data and layoffs in the Job Openings and Labor Turnover Survey (JOLTS), and an even higher correlation (just under 1) between separations-to-employment in the LEHD and quits in the JOLTS.

${ }^{35}$ From appendix table 3, results are quite similar across the different specifications. For results in this section, we cannot perform the final robustness (column VII in table 2 and appendix tables 1 and 2) that includes non-primary jobs. Due to data constraints, these measures are only defined for primary jobs. 
paying firms have negligible impacts, the higher paying firms have larger, positive effects. Interaction terms are typically significant at the $5 \%$ level, and elasticities tend to produce the same patterns. ${ }^{36}$ This is consistent with prediction $\# 3$ from the poaching model, that high-paying firms lay off more workers in a downturn. However, this is also consistent with the other models discussed above.

Thus the gross separations margin is driven by a large decline in separations-to-employment among the lowest paying firms, and a modest increase in separations to non-employment among the higher paying firms. This can be seen in figure 4, which decomposes the separation rate effect into separations to employment (long-dash green) and non-employment (short-dash green). Again we plot the total impact of a 1 ppt increase in the state unemployment rate on these separations rates for each pay quintile. Clearly from the figure, the level impact of the separation rate effect is driven primarily by the impact on separations to employment. The impact of the unemployment rate on these is large and negative for the lowest paying firms, but becomes smaller in magnitude for higher paying firms. Also, higher paying firms see a small positive impact on separations to non-employment.

The inference that a separation to employment was more likely a voluntary move on the part of a worker, while a separation to a full quarter of non-employment was more likely a layoff, is imperfect in that this mapping likely varies across firms and over the business cycle. For example, there is some evidence that monthly job finding rates are lower for skilled workers, likely because they have higher returns to search. Thus a skilled worker might be more likely observed without pay for a full quarter following a layoff. Workers laid off from a low-paying firm may not show up as a separation to non-employment if they find another bad job quickly. Thus the separations-to-employment rate might include more layoffs at low-paying firms, especially in downturns. However, we find an overall large decline in separations-to-employment in the lowest paying firms. Any such misclassification of layoffs, which would imply an increase in separations-to-employment in a downturn (when firms lay off more workers) is clearly not large enough to offset this decline. ${ }^{37}$

Next, we examine hire rates. From table 4, column IV, hires from employment decline by most at the lowest paying firms (the first and second quintiles). Impacts are about 20-40\% smaller in magnitude for the highest paying firms. Once converting to elasticities, however,

\footnotetext{
${ }^{36}$ One exception is shown in column VI of appendix table 4, where firms are categorized by AKM fixed effects. Here there are no systematic impacts on the separations-to-nonemployment margin and across categories, firms do not significantly differ from each other.

${ }^{37} \mathrm{~A}$ similar problem is generated by the fact that we have only a subset of U.S. states. If a worker moves to a state outside this database, that will be classified as a move to non-employment. Since higher skilled workers are more likely to move in response to local labor market conditions (Wozniak 2010), this bias might generate too many separations-to-non-employment from high-paying firms to the extent that they likely employ higher skilled workers. This could explain why the separation-to-non-employment results does not hold for firm fixed effects. Hyatt et al. (2014) and Hyatt and Henderson (2012) go into more detail on this issue. They point out that the inclusion of New York and Ohio into the LEHD in 2000 renders this problem almost moot. We also point out that this finding is secondary and that the main margin of interest is the differential impact on voluntary separations.
} 
we see the effects are roughly similar across groups. This implies that both low-paying and high-paying firms experience large declines in hires that are likely to be from poaching. The poaching model predicts this effect primarily for high-paying firms (\#4). However, a natural interpretation for the decline among low-paying firms that is beyond the scope of the poaching model is the following. After a large decline in voluntary quits, low-paying firms respond with a commensurate decline in hires, targeting roughly the same size workforce. It is plausible, then, that a reduction in poaching in a downturn drives the impact on the hires-from-employment rate at high-paying firms, while a response to a reduction in attrition drives that at lower-paying firms. The latter effect is beyond the scope of the poaching model.

We also find that impacts on hires from non-employment (column V) are pretty small, and even slightly positive for the highest-paying firms, though the latter are only marginally significant. Figure 4 decomposes the hire rate into these two components, showing the total impact of a 1 ppt increase in the state unemployment rate on hires from employment (long-dash red) and non-employment (short-dash red). This decomposition mirrors that for separation rates. The level impact of the hire rate effect is driven primarily by the impact on hires to employment, where the effects of the unemployment rate are most negative for the lowest paying firms.

We therefore find strong support for the 4 predictions of the poaching model here. As we noted, any bias from our mismeasuring voluntary quits likely works against our findings. However, as we pointed out, prediction \#3 (that high-paying firms make relatively more layoffs in a downturn) is also consistent with at least two alternative explanations: that high-paying firms have differentially more sensitive product demand cyclicality or have more difficulty adjusting pay downwards. We explore these next.

\subsection{Cyclicality of Product Demand}

To investigate differential product demand cyclicality, we need information on firm performance other than employment changes. The LEHD has a measure of revenue at the firm level but it is unreliable. Instead, we turn to Compustat North America by Standard \& Poors, the most complete database of U.S. accounting data. ${ }^{38}$ Compustat has reliable balance sheet data for publicly-traded firms. We can therefore ask whether fundamental accounting data are more sensitive to the business cycle at high-quality firms, among those that are publicly traded.

The disadvantage of Compustat data is that it is made up of publicly traded firms, all of whom may be considered reasonably high-quality. The low-paying firms in Compustat may be a poor representation of low-paying firms in the LEHD and the economy as a whole. We therefore first present evidence on whether the patterns presented above that exist in the LEHD also exist in Compustat firms. Though Compustat does not have comparable

\footnotetext{
${ }^{38}$ We obtain these data via Wharton Research Data Services.
} 
earnings or gross worker flows data, it does have annual employment. We can therefore perform our net growth rate analysis using firm size as a proxy for firm pay. ${ }^{39}$

We define size based on average employment in the firm over its lifetime in Compustat (analogous to our pay measure). We then divide firms by size quintile, where the cut points are within industry. ${ }^{40}$ Figure 5 presents growth rates for the smallest and largest quintiles and the differential rate, by year, analogous to those presented in figure $2 .{ }^{41}$ The national unemployment rate is also shown (red dashed line). From the left panel, the larger firms (light line) experience greater amplitudes in growth rates corresponding to business cycle fluctuations, compared to the smaller firms (dark line). From the right panel, the differential growth rate very closely tracks the unemployment rate; when the unemployment rate increases, small firms grow relative to large firms, and vice versa when the unemployment rate decreases. Figure 5 thus shows that even among firms within Compustat, all of whom must be reasonably high quality, the same basic dynamics hold. We hope, then, that analyzing the balance sheet data in Compustat can tell us something about the financial pressures high- and low-paying firms face over the business cycle. ${ }^{42}$

We use the rate of change of quarterly revenue as a proxy for a firm's incentive to hire. Profit maximizing firms will set employment such that marginal cost equals marginal revenue product. Presumably firms with more cyclical product demand will experience accompanying revenue declines. We link the Compustat revenue change data to the LEHD by aggregating quarterly revenue change to the three-digit NAICS level. This allows us to ask whether LEHD pay quintiles are made up of firms in sub-sectors which typically experience more or less business cycle volatility, as measured by Compustat. ${ }^{43}$ Figure 6 plots both percent revenue changes for firms in the lowest and highest quintiles (left panel), as well as the differential revenue change (right panel), analogous to the earlier figures. Reassuringly, revenue change has a strongly cyclical pattern, falling in recessions and rising in booms. Both panels, however, show little difference across low- and high-paying firms over the business cycle. High-paying firms experienced a slightly larger decline in revenue change during the Great Recession, as can be seen in the left panel where the gray line declines by more than the dark line in 2009, and in the right panel where the differential rate spikes up in 2009. However, this pattern is not systematic over the time period as a whole. For example, in the

\footnotetext{
${ }^{39}$ Size is a common proxy for pay since the two variables are highly correlated. Moscarini Postel-Vinay (2012) show in a large number of countries that small firms grow relative to large firms in slack labor markets, while the opposite is true in tight labor markets.

${ }^{40}$ Since most firms in Compustat have a larger, national presence, we do not use geographic location information.

${ }^{41}$ The unfiltered series is clearer so we present that one, and of course the annual data do not need seasonal adjustments.

${ }^{42}$ Though not shown here, in regression analysis, the relationship between net employment changes and the national unemployment rate is statistically significantly larger in magnitude (more negative) at firms in the largest size quintile compared to the smallest.

${ }^{43}$ We are not permitted to link Compustat data to the LEHD at the firm level because of confidentiality concerns.
} 
2001 recession, the differential rate declined meaning that low-paying firms took a relatively bigger hit to revenue. This figure is therefore inconsistent with the notion that high-paying firms are more sensitive to the business cycle.

Based on the evidence presented here, we think it unlikely that differential business cycle sensitivity in the product market is driving our results. The sub-sectors where low- and high-paying firms are typically found do not experience differential sensitivities, as reported by Compustat. Though we should caution that this exercise needs to be taken with a grain of salt, since it is based on an unrepresentative set of firms.

\subsection{Downward earnings rigidities}

We investigate downward earnings rigidities in the LEHD using total quarterly earnings for a worker from a given firm. To be clear, this is not the typical measure used in papers on wage rigidities, which focus on hourly rates of pay. Instead, this measure incorporates a number of dimensions along which firms can adjust labor costs besides lowering the base rate of pay, for example hours, overtime and bonuses. We thus ask whether firms seem to have differential abilities to cut on their labor bill (without laying workers off) and whether this varies with the business cycle. A finding that high-paying firms have more difficulty cutting pay in downturns could explain their relative increase in layoffs and more cyclically sensitive growth rates. Also, the fact the high-paying firms continue to hire relatively more than low-paying firms, despite an increase in layoffs, is consistent with the literature showing that starting wages are more pro-cyclical than incumbent wages (Martins, Solon and Thomas 2010).

To test this, we follow a similar methodology to Dickens et al. (2007). We measure nominal annual pay changes in earnings, $\Delta p_{i t}$, for job stayers. ${ }^{44}$ For a firm, $f$, in time period $t$, we then estimate the nominal pay rigidity as per equation 3 . That is, for a firm with $N$ workers who have a valid pay change measure, we take the number whose annual pay change was equal to 0 and divide that by the number whose pay change was less than or equal to 0 . In practice, we define a pay change to be equal to 0 if it is within $\pm 1 \%$, to allow for some noise, and results are robust to larger bounds.

$$
\text { nominal pay rigidity }_{f t}=\frac{\sum_{i=1}^{N} \mathbf{1}\left(\Delta p_{i t}=0\right)}{\sum_{i=1}^{N} \mathbf{1}\left(\Delta p_{i t} \leq 0\right)}
$$

This measure proxies for the following: Among workers who were at risk of receiving a

\footnotetext{
${ }^{44} \mathrm{~A}$ worker must have 10 continuous quarters of earnings to be included in the sample. At the quarterly level, issues arise such as differences in the number of pay cycles within a quarter that vary across firm and across calendar year. To avoid additional noisiness, we measure annual pay changes. We also trim the distribution of earnings changes to those who had more than $\pm 50 \%$ changes, since these presumably represent errors in reporting.
} 
nominal pay decrease, what share did NOT receive one? We find that on average over our time period, this share is roughly 0.25 . We then average these within our firm-pay buckets, weighting by average employment at a given date, to gain a sense of whether firms of varying quality experience differential pay rigidities over the business cycle.

Figure 7 plots these estimates over time for firms in the lowest pay quintile (dark line), and firms in the highest pay quintile (light line line) in the left panel and the differential rate in the right panel, along with the unemployment rate. As can be seen, pay rigidity has a cyclical pattern, falling in recessions and rising in booms. ${ }^{45}$ However, the left panel very clearly shows that high-paying firms have a much larger drop in rigidities in recessions and a larger increase in booms. The differential rate, for the most part, moves opposite the unemployment rate, meaning that low-paying firms become relatively less rigid in booms and relatively more rigid in busts.

We therefore find that high-paying firms are relatively more likely to reduce pay of incumbents at the margin in a downturn. It seems then unlikely that an inability to adjust pay drives the relative increase in layoffs at high-paying firms. However, we caution that our measure is selected in that we can only estimate rigidities for stayers at a firm. We have already shown that high- and low-paying firms differ in their gross separation rates over the business cycle. For example, a high-paying firm might lay off workers whose pay cannot be adjusted, leaving only those whose pay can be adjusted. However, the evidence presented here suggests that high-paying firms are able to adjust labor costs in recessions, relative to low-paying firms, by cutting earnings. Therefore, we do not believe differential earnings rigidities can be driving our results.

\subsection{Alternative explanations}

Managerial practices at high- and low-paying firms surely differ along a variety of dimensions. Differences might arise if low-paying firms are always closer to the margin of survival. For example, the "pit stop" model of management (Koenders and Rogerson 2005) says that in booms managers are focused on growth and in busts must focus on efficiency and cut workers. Given positive correlations between pay, productivity, and size, it could be that low-paying firms are always closer to the margin of survival and therefore always focused on efficiency. This would result in a relatively greater need for high-paying firms to lay off workers in downturns. However, such a theory suggests the counter-intuitive notion that low-paying firms manage more efficiently. This seems on the surface unlikely, given that low-paying firms are on average smaller, have higher churn, and are probably less productive.

In contrast, one might suppose that given their lower productivity, smaller size, and likely lower probability of survival, low-paying firms manage inefficiently. While high-paying firms

\footnotetext{
${ }^{45}$ The data show rigidity for pay changes that occur over the next year. Thus the cyclical pattern looks as though it leads the recession bars.
} 
lay off workers in economic downturns, low-paying firms do less of this, even though they should. This seems unlikely for a couple of reasons. First, such poor management should result in relatively more firm deaths in bad times at low-paying firms. Our employment measures include firm deaths yet we still find that on average, low-paying firms grow relative to high-paying firms in busts, including and despite any shrinkage from firm deaths. Second, reinspecting figure 4, we note the larger adjustment in gross flows at low-quality firms. Faced with a large decline in voluntary quits, low-paying firms respond with a commensurate decline in hiring. This suggests that low-paying firms do respond to their business environment and target a particular sized workforce. ${ }^{46}$

Finally, we point out that a simple compensating differentials framework can yield our results. In equilibrium, volatile jobs need to be higher paying in order to make the marginal worker indifferent between working there and a low-paying job with stable employment. However, this is also on the surface at odds with some evidence in the data. From table 1, the lowest paying firms have $20 \%$ turnover each period, while the highest paying firms have half that. They also have larger rates of separation-to-non-employment, a more negative risk. Thus the lower paying jobs are on average much more unstable.

We therefore conclude that the body of evidence presented in sections 4 and 5 is most consistent with the Moscarini Postel-Vinay (2013) poaching model. This is because we find support for all four predictions mentioned above, no support for differential product market cyclicality or earnings rigidities, and these final alternative explanations seem unlikely. In other words, a partial collapse of the job ladder in downturns leaves workers at the bottom of the job ladder stuck when they otherwise would have liked to move up the ladder. These findings have important implications for the impacts of recessions on workers' careers, which we explore next.

\section{Impacts on the job ladder}

In this section we use data on individual workers and their transitions across firms to quantify the effect of the business cycle on the job ladder, established above, for workers at various starting points and how this impacts careers. We first examine the impacts on mobility for incumbent workers. We then estimate impacts for new job matches in light of the fact that job seekers seem to be particularly scarred by recessions.

\subsection{All Workers}

In this subsection, we assess the level of upward mobility as a function of starting pay quintile and how this changes over the business cycle. Table 5 reports estimated transition matrices

\footnotetext{
${ }^{46}$ We also point out that this reduction in hires by low-paying firms, which offsets any impact from declining poaching at high-paying firms, is necessary to rationalize the finding that revenue does not vary differentially over the business cycle.
} 
across firm pay quintiles over one quarter. We fit effects for a boom (left panel) and a bust (right panel) based on ordered logit regressions. ${ }^{47}$

Focusing first on a boom and for workers who were in the lowest quintile in $t$ (left panel, first column), we estimate that $89.9 \%$ of these workers remain in the lowest paying firms in $t+1$ (this could be their firm in $t$ or a different firm in the same pay quintile). This means that $10.1 \%$ move up the job ladder, with the vast majority moving up only one rung. One way to quantify the magnitude of this chance of upgrading is to assign average pay to each quintile (from table 1) and predict what kind of firm the average worker will be in one quarter later. This is shown in the bottom row. Those beginning in the lowest quintile in $t$ will on average be at a firm whose average pay is $\$ 1,936$ in $t+1$. This represents $5 \%$ advancement above their starting point which was $\$ 1,842$ (average pay at the lowest quintile).

Workers starting at higher rungs of the ladder could upgrade, downgrade or stay put. For example at the second rung workers stay in their current rung $72 \%$ of the time, and upgrade or downgrade with roughly equally probabilities, around $14 \%$. Workers in the highest rung in $t$ are most likely to survive in their current rung, at $94 \%$.

The right panel reports what our estimates imply for these transition probabilities in a bust. Transitions for incumbents in rungs 2-4 are essentially unaffected by the bust, while workers in the top rung in $t$ are a bit less likely to hold onto their position until $t+1$. The largest impacts are on workers in the lowest paying firms. Only $8 \%$ of these workers upgrade firms over the quarter, one-fifth fewer than in a boom. In $t+1$ these workers have only upgraded to a firm paying $\$ 1,917 /$ month, $\$ 19$ less (or a $20 \%$ smaller expected advancement) than in a boom.

In this paper, we establish a partial collapse of the job ladder in a downturn. We show that for workers unlucky enough to be at the bottom of the ladder at that point, the impacts are large. They can expect to achieve only $80 \%$ of the advancement over the next quarter than would be expected in boom times. This back of the envelope calculation is instructive because it allows us to quantify effects based solely on the the firm-level dynamics established in this paper and strips away any pay dynamics for individual workers. Consistent with sections 4 and 5, we find a substantial breakdown of the job ladder for workers in the lowest rung, as well as a small loss of position for workers in the highest rung, and not much change for those in the middle. ${ }^{48}$

\footnotetext{
${ }^{47}$ We estimate ordered logits of pay quintile in $t+1$ on pay quintile in $t$, the unemployment rate and interactions for individuals who are employed in both $t$ and $t+1$. We report regression coefficients for several specifications in appendix table 7 . We find that a higher unemployment rate in $t$ significantly reduces the likelihood of being in a higher pay quintile in $t+1$, but only for workers in the lowest quintile in $t$. The fitted transition matrices in table 5 use coefficients from column IV of appendix table 7 and a $4.2 \%$ unemployment rate for a boom and $10.4 \%$ unemployment rate for a bust.

${ }^{48} \mathrm{It}$ is worth pointing out that these results are selected since they restrict to those working in $t+1$. Though not shown, we estimate that a higher unemployment rate in $t$ reduces the probability of working in $t+1$, but more so for workers at the top of the job ladder in $t$. Our estimates imply that in the Great Recession, workers in the top rungs of the ladder had a 2 ppt increased probability of transitioning to nonemployment in the next quarter, while workers in the bottom rung were unaffected. Thus table 5 cannot
} 


\subsection{New Entrants}

The relative advantage low-paying firms retain in a downturn might help to explain why the two groups mentioned in the introduction, recent college graduates and those displaced from a job where they had high tenure, face substantial earnings losses when these events occur in a downturn. ${ }^{49}$ Our estimates imply that the distribution of jobs shifts towards the lower paying firms in a downturn and that these jobs become stickier. How much of the long-term earnings losses for each of the groups mentioned above can be accounted for by this shift in the distribution of jobs and a short-term break down of the job ladder?

We first ask how the distribution of job matches varies over the business cycle. Table 6 reports implied distributions of new job matches across firm pay quintiles for a boom and a bust and is based on an ordered logit regression. ${ }^{50}$ In a boom (first column), $42.2 \%$ of new matches are to the lowest paying firms. These firms are overrepresented in job starts compared to the stock of workers (which is by construction evenly distributed across firm type). This is because of the especially high churn rates at the lowest paying firms. In contrast only $4.6 \%$ of new matches are to the highest paying quintile. The bottom row shows that the average worker matching to a firm in a boom is at a firm paying $\$ 2,782$, on average. This is lower than the $\$ 3,811$ average for the stock of workers.

In a bust (second column), the firm quality distribution shifts downward. Workers are about 4 ppts more likely to match to the lowest paying firms and about a point less likely to match to each of the higher quintiles. This amounts to a nearly $\$ 90$ reduction in firm quality (average firm pay for the average matching worker) or $3 \%$ less than those matching in booms. Of course this exercise is merely descriptive in the sense that we have not adjusted for ability differences across those matching in booms versus busts. There could be negative selection of workers matching to firms in recessions, since those with a good current position stay put (see Kahn (2013) for evidence on this). However, it is also at least consistent with the relative shift of jobs towards lower paying firms, demonstrated above.

Next, table 7 helps us understand whether workers are differentially likely to upgrade from their initial match, as a function of the economy at the time of that match. We use an ordered logit to predict for workers matching in $t$, firm quality in $t+3$ as a function of firm

fully quantify the regressive effects of a recession on a worker's position when starting at higher rungs.

${ }^{49}$ Davis and von Wachter (2011) estimate that the impact of job displacement for those with at least 3 years of tenure is a $20 \%$ drop in the present discounted value of lifetime earnings, for those displaced in a recession. The impact for those displaced in a boom is a 12\% drop. Altonji, Kahn, and Speer (2014) estimate that those graduating from college into a large recession in the U.S. experience an average drop in annual earnings of roughly $2 \%$ per year over the first decade of a career, and similar impacts on wage rates. Oreopoulos, von Wachter and Heisz (2012) find similar losses in Canada and show they manifest through initial matches to worse (smaller) firms.

${ }^{50} \mathrm{We}$ estimate ordered logits of firm pay quintile on the unemployment rate and various controls among workers who started a job in $t$. Appendix table 8 reports regression results for several specifications. The fitted distributions in table 5 use coefficients from column IV of appendix table 8 and a $4.2 \%$ unemployment rate for a boom and $10.4 \%$ unemployment rate for a bust. 
quality in $t$ and the unemployment rate. ${ }^{51}$ Workers who match to the lowest ranked firms in a boom (left panel, first column) do tend to upgrade in the first year following the match. Only $62.5 \%$ of these workers remain in a low paying firm, while a quarter have upgraded to the 2 nd pay quintile and more than $10 \%$ have actually moved up to an even higher quintile. On average, a worker matching to the lowest paying firms in a boom is at a firm whose average pay is $\$ 2,346$ three quarters later. This is a $\$ 500$ advancement above the average pay at the lowest paying firms $(\$ 1,842)$ or $27 \%$. Workers starting out in higher rungs are also slightly more likely to hold their position or advance, than to backslide. For example, $27 \%$ of workers matching to the 3rd quintile remain at that quintile, while another $27 \%$ advance to the 4 th or 5 th quintiles. Among those matching to the highest paying firms, $65 \%$ retain their position 3 quarters later, when matching in a boom. However, a quarter slide back to the 4 th quintile and $10 \%$ slide back further than that.

For those matching in a bust, these figures look fairly similar, with some important differences. Above, we estimated that in busts there is a substantial decline in exits-toemployment from the lowest paying firms. This effect means that workers matching to the lowest paying firms in a bust will probably be less likely to upgrade, initially. Indeed, the right panel of table 7 shows that $63.8 \%$ of those matching to the lowest paying firms in a bust retain their position; thus only $36.2 \%$ advance, 1.4 ppts less than for those matching in a boom. In dollar terms, the average worker moves to a firm whose average pay is $\$ 2,325$ when matching in a bust, or $\$ 20$ less advancement $(4.2 \%)$ than those matching in a boom.

Above, we also estimated that the highest paying firms are more likely to make layoffs (i.e., separations to non-employment) in a bust. From table 7, it looks as though these layoffs hit new entrants especially hard. Workers matching to a top paying firm in a bust are far less likely to maintain their position, $57.5 \%$, compared to $65 \%$ in a boom. In dollar terms, this amounts to a $\$ 214$ lower average firm pay in $t+3$. It is thus much worse to match to a high-paying firm in a bust than a boom. Perhaps these firms look to clean out some of their incumbent workforce in a bust, but still need some temporary, lower skilled workers, to eke out their production needs.

Workers matching to firms in the middle of the pay distribution do not see much of a change in mobility when matching in a bust compared to a boom.

Overall, how do workers fare when matching to a firm in a bust compared to a boom? If we assume the matching probability does not change over the business cycle (that is, ignore the results from table 6), and instead fit the boom match probabilities, we get that the average worker is at a firm paying $\$ 2,9463$ quarters later, if matching to a boom, and only

\footnotetext{
${ }^{51}$ Regression results are reported in appendix table 9. Estimates in table 7 come from column IV. We find that the unemployment rate at time of match is negatively related to firm quintile 3 quarters later, for workers matching to the lowest quintile (the omitted category). This effect is fully offset for workers matching to the 2 nd and 3rd quintiles, and halfway offset for those matching to the 4 th quintile. The effect is exacerbated for those matching to the highest quintile in $t$, and in total is 5 times larger than the base effect.
} 
$\$ 2,929$ if matching in a bust. These are both advancements relative to the initial match, which we reported above as $\$ 2,782$ in a boom. This nearly $\$ 20$ difference or $10 \%$ smaller advancement for those matching in a bust is attributed solely to the reduced probability of upgrading after matching. If we also factor in that workers are more likely to match to low paying firms in a recession, we get the combined effect. The average worker, 3 quarters later, is at a firm paying on average $\$ 2,871$. Thus the full effect of matching in a bust, compared to a boom, is a $\$ 75$ lower average firm quality 3 quarters later. This is $2.6 \%$ of the average earnings in $t+3$ for someone matching in $t$ in a boom, or half of their typical advancement.

The most comprehensive analysis of graduating from college in a downturn in the U.S. (Altonji, Kahn, and Speer (2015)) finds that in the first year after graduation earnings losses total roughly $10 \%$ and converge to $4 \%$ by 3 years out. Our back-of-the-envelope calculation shows that workers matching in a bust spend their first year at firms paying $2.6 \%$ less than those matching in a boom. Thus the job ladder dynamics established in this paper can account for nearly a third of the initial earning losses and half of the persistent earnings losses over an early career for those graduating in a bust compared to a boom.

The same disclaimer on causality applies here. However, we find these results interesting, consistent with the reduction in voluntary mobility estimated above, and useful for considering the possible magnitudes the dynamics presented above can have in terms of impacts on workers and the job ladder.

\section{Conclusion}

In this paper, we use employer-employee matched U.S. data to study net and gross worker flows over the business cycle as a function of firm pay. We find that low-paying firms fare relatively better in downturns; their growth rates are unaffected by the business cycle. The evidence suggests that in normal times, low-paying firms suffer from a large worker separation rate, and therefore also do a lot of replacement hiring. In bad times, separations decline substantially at these firms, especially for those that look voluntary, and they aim for a commensurate reduction in hires. This keeps the growth rate relatively constant over the business cycle. Higher paying firms experience less of an impact on their separations to employment but still a large reduction in hires. The highest paying firms also increase separations to non-employment, which most likely represent layoffs. As we have said, these findings are consistent with the Moscarini Postel-Vinay (2013) poaching model, though we cannot completely rule out a small role for differential sensitivity to the business cycle driven by consumer demand.

While previous research has emphasized that match quality may decline in recessions due to a lack of workforce reallocation (Barlevy termed this the "sullying" effect of recessions

in his 2002 paper), we provide evidence of an additional sullying effect. The types of jobs workers get stuck in are more likely to be low quality. Our results suggest that the reduced 
ability to move on to better matches caused by a recession has a greater impact on workers in low-quality firms compared to those in high-quality firms. We estimate that a large recession reduces the probability of advancing out of the lowest paying firms by $20 \%$.

These results also have important implications for the literature on the differential impact of recessions on workers. The literature has shown that entering the labor market in a recession (Kahn (2010), Oreopoulos, von Wachter and Heisz (2012), Altonji, Kahn and Speer (2014)) and being displaced from a long-term job in a recession (Davis and von Wachter 2010) each have particularly long-lasting, negative earnings impacts. Both groups were forced to search for, and likely accept, a job in a downturn. Our results indicate that workers matching in recessions are more likely to go to a low-paying firm, and more likely to stay there once matched. These effects combine to an estimated $2.6 \%$ drop in average firm quality a year after matching, for those matching in a recession compared to a boom, or $\$ 75 /$ month lower average firm pay. These workers thus lose out on roughly half of the advancement made by workers matching in a boom. Our estimates are based solely on typical pay in these firms, and do not reflect any heterogeneity within firm. Also, they do not pick up any scarring effects from spending time at a low-paying firm. These could include both how a worker is perceived to potential employers, but also impacts on human capital accumulation and the development of networks. These impacts could be large and long-lasting.

\section{References}

[1] Abowd, John, Bryce Stephens, Lars Vilhuber, Fredrik Andersson, Kevin L. McKinney, Marc Roemer, and Simon Woodcock (2009). "The LEHD Infrastructure Files and the Creation of the Quarterly Workforce Indicators" In Producer Dynamics: New Evidence from Micro Data, Vol 68, Studies in Income and Wealth, ed. Timothy Dunn, J. Bradford Jensen and Mark J. Roberts, 149-230. Chicago: University of Chicago Press.

[2] Abowd, John, Francis Kramarz, and David Margolis (1999): "High Wage Workers and High Wage FIrms," Econometrica, vol 67(2), pp. 251-333.

[3] Akerlof and Yellen (1985), "A Near Rational Model of the Business Cycle, with Wage and Price Inertia," Quarterly Journal of Economics, 100, suppl., pp. 823-38.

[4] Altonji, Joseph G., Lisa B. Kahn, and Jamin D. Speer (2014) "Cashier or Consultant? Entry Labor Market Conditions, Field of Study, and Career Success," NBER working paper \#20531.

[5] Barlevy, Gadi (2002), "The Sullying Effect of Recessions," The Review of Economic Studies, 69(1), pp. 65-96. 
[6] Bernard, Andrew B., J. Bradford Jensen, Stephen J. Redding, and Peter K. Schott (2007), "Firms in International Trade," Journal of Economic Perspectives, 21(3), pp. 105-130.

[7] Bils, Mark and Peter Klenow (1998), "Using Consumer Theory to Test Competing Business Cycle Models," Journal of Political Economy, 106(2).

[8] Bils, Mark and Kenneth J. McLaughlin (2001), "Inter-Industry Mobility and the Cyclical Upgrading of Labor," Journal of Labor Economics, 19(1), pp. 94-135.

[9] Bowlus, Audra. (1993), "Matching Workers and Jobs: Cyclical Fluctuations in Match Quality," Journal of Labor Economics, 13(2), pp. 335-350.

[10] Brown, C. and J. Medoff (1989), "The Employer Size-Wage Effect," Journal of Political Economy, 97(5).

[11] Burdett, K. and D. Mortensen (1998), "Wage Differentials, Employer Size, and Unemployment," International Economic Review, 39(2), pp. 257-273.

[12] Burgess, Simon, Julia Lane and David Stevens (2000), "Job Flows, Worker Flows, and Churning," Journal of Labor Economics, 18(3): pp. 473-502.

[13] Caballero, R. and Hammour, M. (1994), "The Cleansing Effect of Recessions, American Economic Review, 84, pp. 1350-1368.

[14] Caballero, R. and Hammour, M. (1996), "On the Timing and Efficiency of Creative Destruction," Quarterly Journal of Economics, 111, pp. 805-852.

[15] Campbell, B., H. Chiang, J. Haltiwanger, L. Hunter, R. Jarmin, N. Nestoriak, T. Park, and K. Sandusky (2005), "Firm Performance, Workforce Quality, and Workforce Churn," mimeo.

[16] Chari, V. V., L. Christiano and P. Kehoe (2007), "The Gertler-Gilchrist Evidence on Small and Large Firm Sales," mimeo.

[17] Davis, Stephen J., John Haltiwanger and Scott Schuh (1996), Job Creation and Destruction, MIT Press.

[18] Davis, Stephen and Till von Wachter (2011), "Recessions and the Cost of Job Loss," Brookings Papers on Economic Activity, Fall.

[19] Dickens, W., L. Goette, E. Groshen, S. Holden, J. Messina, M. Schweitzer, J. Turunen, M. Ward, (2007), "How Wages Change: Micro Evidence from the International Wage Flexibility Program," Federal Reserve Bank of New York Staff Reports, staff report no. 275. 
[20] Farber, Henry (1999), "Mobility and Stability: the Dynamics of Job Change in Labor Markets," in O. Ashenfelter and D. Card (eds.), Handbook of Labor Economics, vol. 3, North Holland, pp. 2439-2483.

[21] Fort, Teresa, John Haltiwanger, Ron Jarmin and Javier Miranda (2013), "How Firms Respond to Business Cycles: The Role of Firm Age and Firm Size," NBER working paper \#19134

[22] Gertler and Gilchrist (1994), "Monetary Policy, Business Cycles, and the Behavior of Small Manufacturing Firms," The Quarterly Journal of Economics, 109 (2), 309-340.

[23] Gomes, J., J. Greenwood, and S. Rebelo (2001), "Equilibrium Unemployment," Journal of Monetary Economics, 48(1), pp. 109-152.

[24] Hall, Robert (1991), "Labor Demand, Labor Supply and Employment Volatility," in NBER Macroeconomics Annual (Cambridge: MIT Press)

[25] Hall, Robert (2005a), "Employment Fluctuations with Equilibrium Wage Stickiness," American Economic Review, 95(1), pp. 50-65.

[26] Hall, Robert (2005b), "Job Loss, Job Finding, and Unemployment in the U.S. Economy over the Past Fifty Years," NBER Macroeconomics Annual 2005, pp. 101-137.

[27] Haltiwanger, John, Henry Hyatt, and Erika McEntarfer (2014), "Cyclical Reallocation of Workers across Employers by Firm Size and Firm Wage," mimeo.

[28] Haltiwanger, John, Ron Jarmin and Javier Miranda (2013), "Who Creates Jobs? Small vs. Large vs. Young," Review of Economics and Statistics, 95(2), pp. 347-361.

[29] Hurst, Erik and Benjamin Pugsley (2011), "What Do Small Businesses Do?", Brookings Papers on Economic Activity, Fall.

[30] Hyatt, Henry and Erika McEntarfer (2012a) "Job-to-Job Flows and the Business Cycle" American Economic Review Papers and Proceedings, 103(3), pp. 580-583.

[31] Hyatt, Hentry, and Erika McEntarfer (2012b), "Job-to-Job Flows and the Business Cycle," US Census Bureau Center for Economic Studies Paper No. CES-WP-12-04.

[32] Hyatt, Henry, Erika McEntarfer, Kevin McKinney, Stephen Tibbets, and Doug Walton (2014), "Job-to-Job Flows: New Labor Market Statistics from Linked EmployerEmployee Data," Joint Statistical Meetings Papers and Proceedings, forthcoming.

[33] Jovanovic, Boyan (1979), "Job Matching and the Theory of Turnover," The Journal of Political Economy, 87(October), pp. 972-90. 
[34] Kahn, Lisa (2010), "The Long-Term Consequences of Graduating from College in a Recession," Labour Economics, 17(2): pp. 303-316.

[35] Kahn, Lisa (2013), "Asymmetric Information between Employers," American Economic Journal: Applied Economics, 5(4): pp. 165-205.

[36] Koenders, K. and R. Rogerson (2005), "Organizational Dynamics Over the Business Cycle: A View on Jobless Recoveries," Federal Reserve Bank of St. Louis Review.

[37] Lazear, Edward and Jim Spletzer (2012), "Hiring, Churn and the Business Cycle" American Economic Review Papers and Proceedings, 102(3): pp. 575-579.

[38] Martins, P., G. Solon and J. Thomas, "Measuring What Employers Do About Entry Wages Over the Business Cycle: A New Approach," American Economic Journal: Macroeconomics, forthcoming.

[39] Mortensen, D. and C. Pissarides (1994), "Job Creation and Job Destruction in the Theory of Unemployment," Review of Economic Studies, 61, pp. 397-415.

[40] Moscarini, Giuseppe and Fabien Postel-Vinay (2013), "Stochastic Search Equilibrium," Review of Economic Studies, 80(4), pp. 1545-1581.

[41] Moscarini, Giuseppe and Fabien Postel-Vinay (2012), "The Contribution of Large and Small Employers to Job Creation in Times of High and Low Unemployment," American Economic Review, 102 (6), pp. 2509-2539.

[42] Okun, Arthur (1973), "Upward Mobility in a High Pressure Economy," Brookings Papers on Economic Activity, 207-52.

[43] Oreopoulos, Phil, Till von Wachter and Andrew Heisz (2012), "The Short- and LongTerm Career Effects of Graduating from College in a Recession," American Economic Journal: Applied Economics, 4(1) pp. 1-29.

[44] Pissarides, C. (2009), "The Unemployment Volatility Puzzle: Is Wage Stickiness the Answer?" Econometrica, 77(5), pp. 1339-69.

[45] Schumpeter, J. (1939), Business Cycles (New York: McGraw-Hill).

[46] Serafinelli, M. (2012), "Good Firms, Worker Flows and Productivity," mimeo.

[47] Sharpe, Stephen (1994), "Financial Market Imperfection, Firm Leverage, and the Cyclical of Employment," American Economic Review, 84 (4), pp. 1060-74.

[48] Shimer, R. (2004), "The Consequences of Rigid Wages in Search Models," Journal of the European Economic Association, 2 (2-3), pp. 469-79. 
[49] Shimer, R. (2005), "The Cyclical Behavior of Equilibrium Unemployment and Vacancies," American Economic Review, 95(1), pp. 25-49.

[50] Weiss, Andrew (1980), "Job Queues and Layoffs in Labor Markets with Flexible Wages," Journal of Political Economy, 88(June), pp. 526-38.

[51] Wozniak, Abigail (2010), "Are College Graduates More Responsive to Distant Labor Market Opportunities?" Journal of Human Resources, Vol 45(4), pp. 944-970. 
Figure 1:

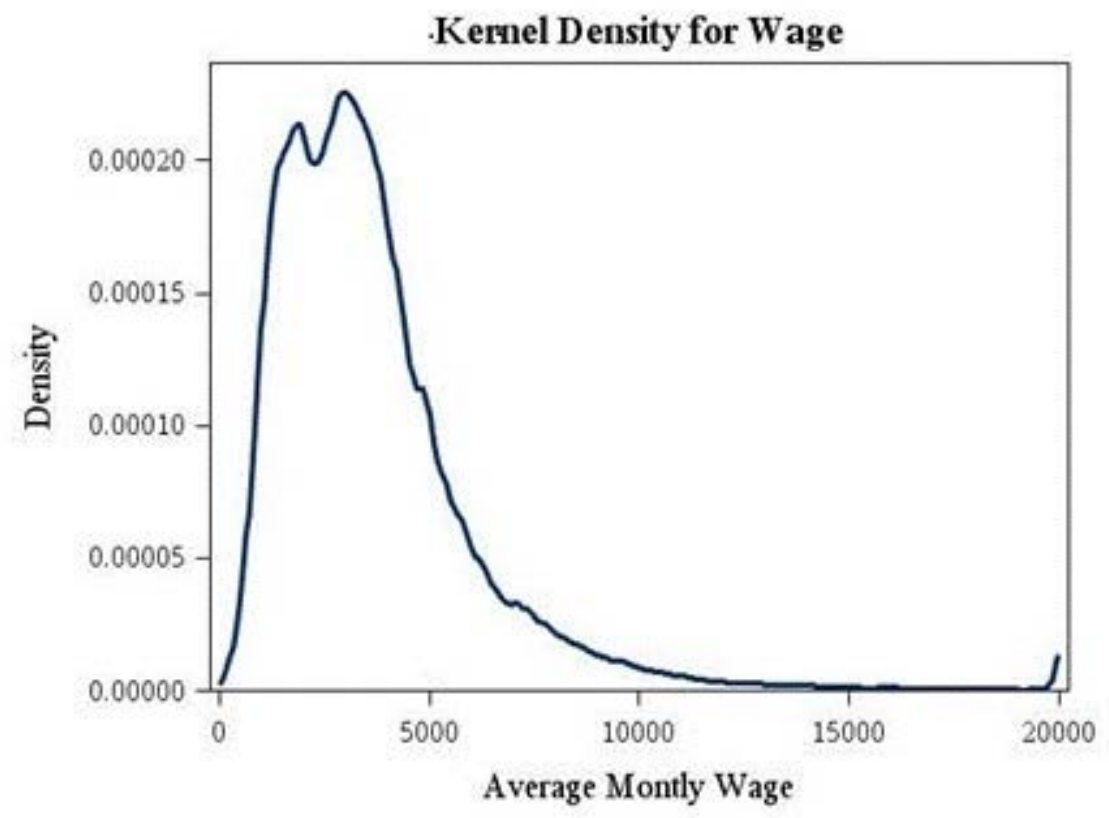




\section{Figure 2: Growth Rate Time Series by Firm Pay Quintile}
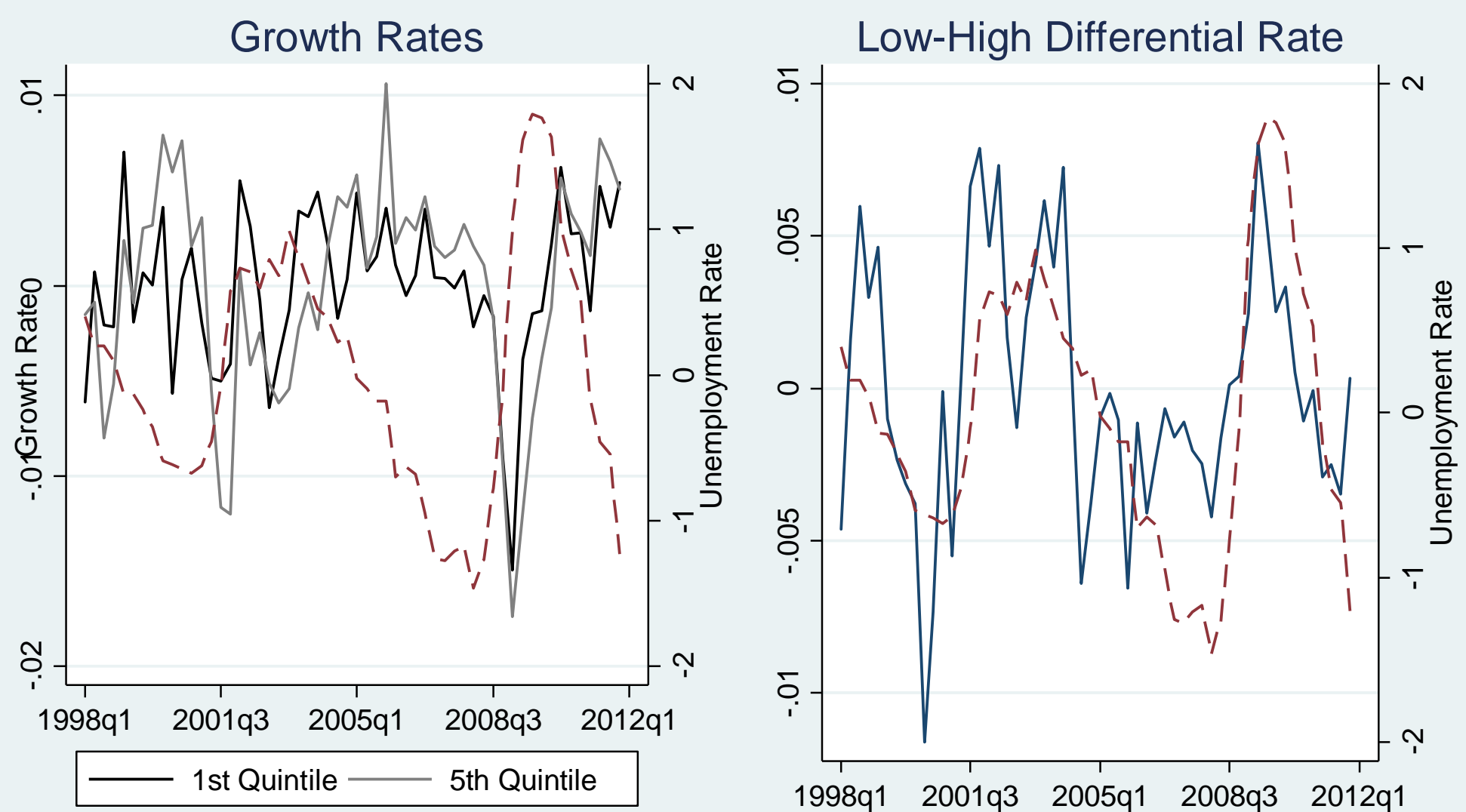

\section{Date}

HP Filtered and Seasonally Adjusted

Dashed Line = Unemployment Rate (left axis) 
Figure 3a: Separation Rate Time Series by Firm Pay Quintile
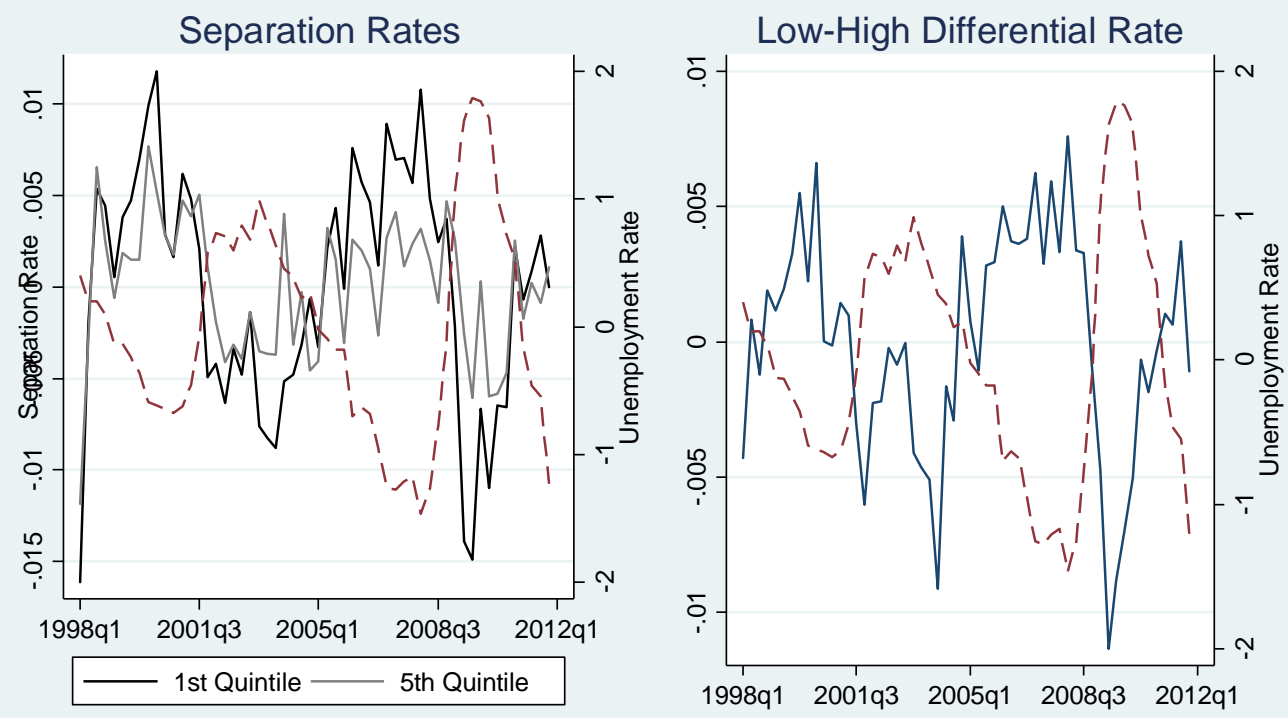

Date

HP Filtered and Seasonally Adjusted

Dashed Line $=$ Unemployment Rate (left axis)

Figure 3b: Hire Rate Time Series by Firm Pay Quintile

Hire Rates

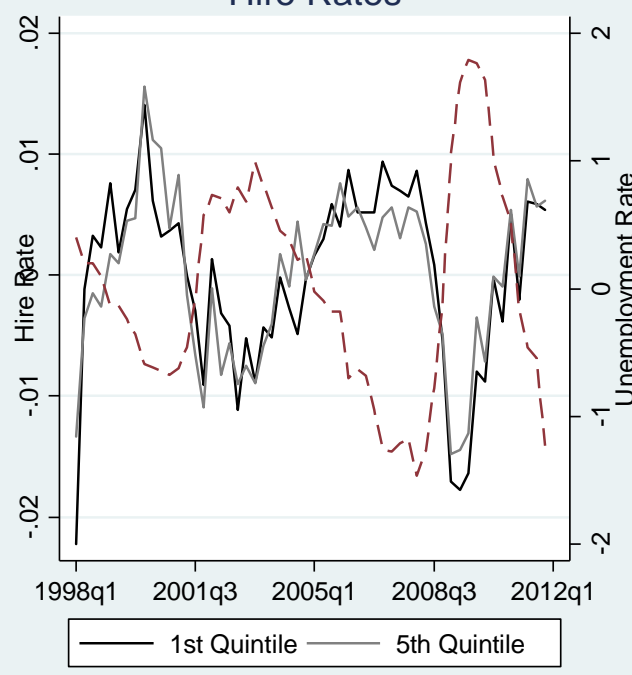

Low-High Differential Rate

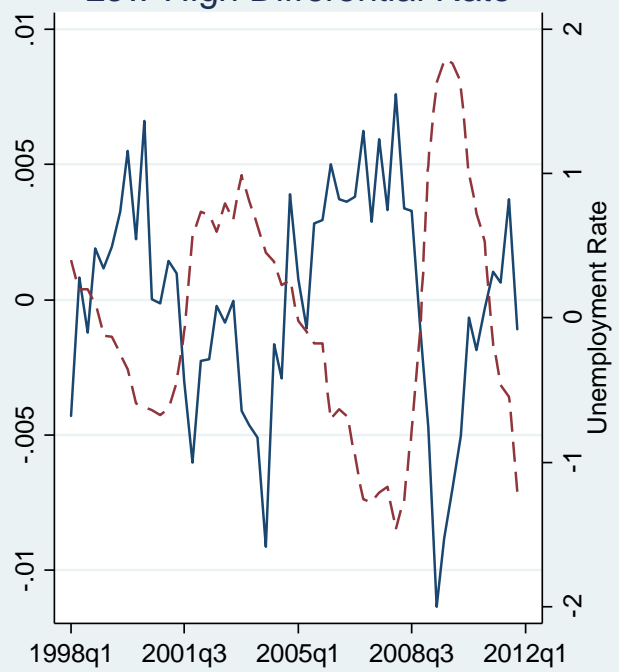

Date

HP Filtered and Seasonally Adjusted

Dashed Line = Unemployment Rate (left axis) 
Figure 4: Impact of State U Rate on Worker Flows by Wage Quintile

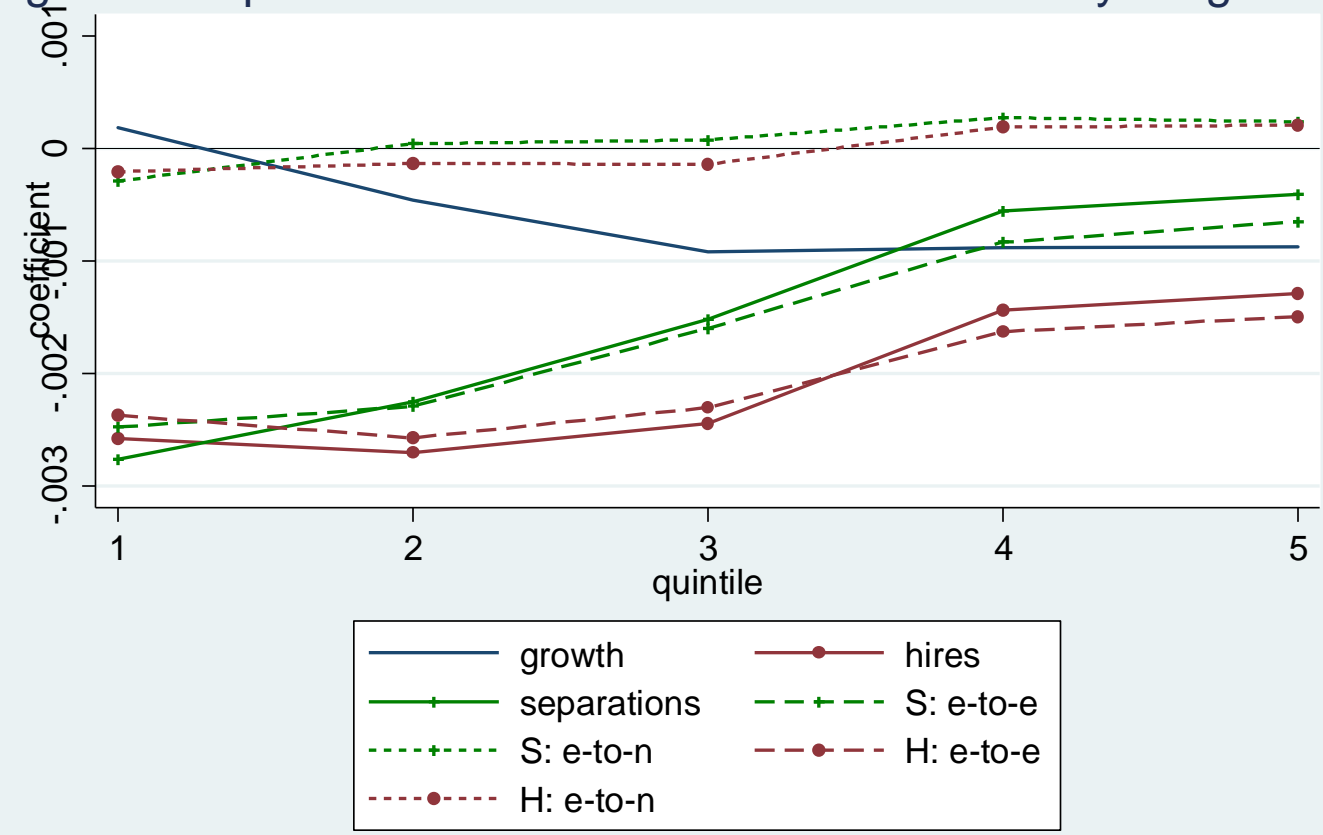

Plots interaction of $U^{*}$ quintile (rel to worst quintile) plus main effect of $U$

Figure 5: Compustat Growth Rates by Firm Size Quintile
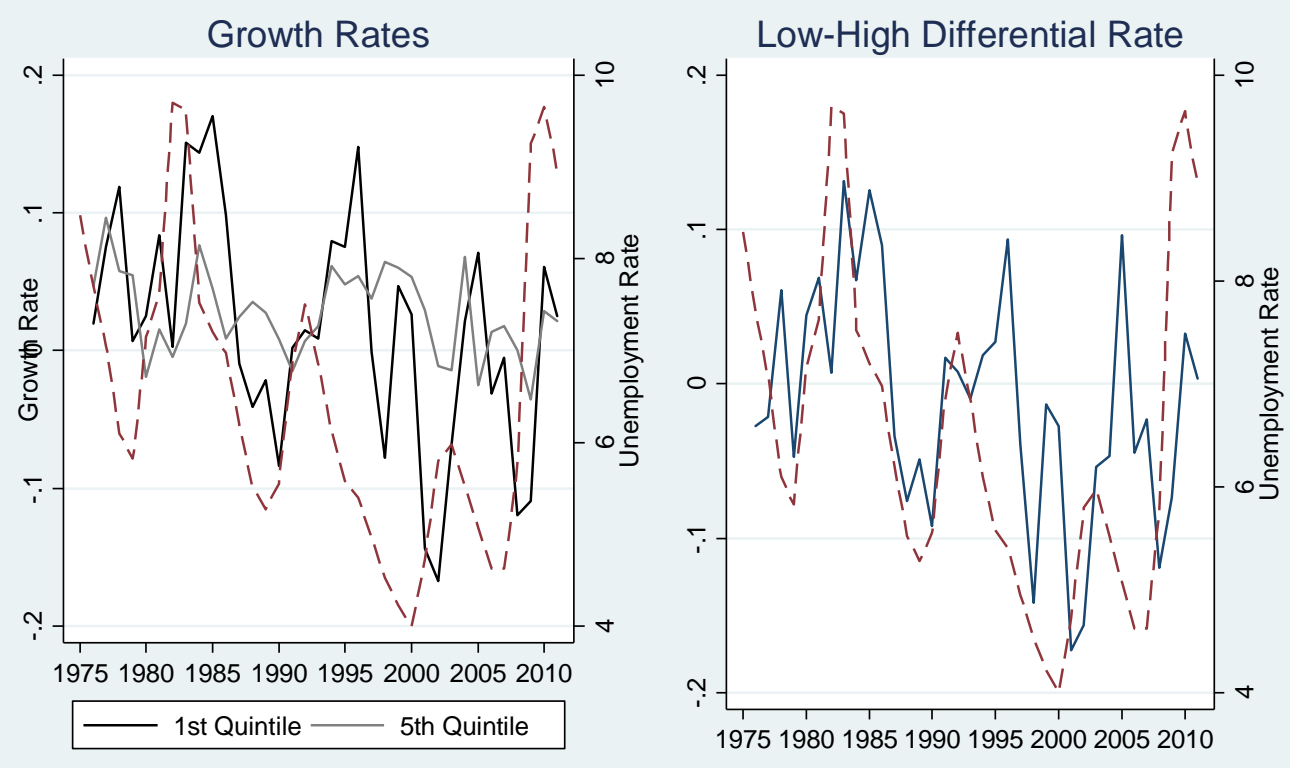

Year

Dashed Line = Unemployment Rate (left axis) 


\section{Figure 6: Revenue Change Time Series by Firm Pay Quintile}
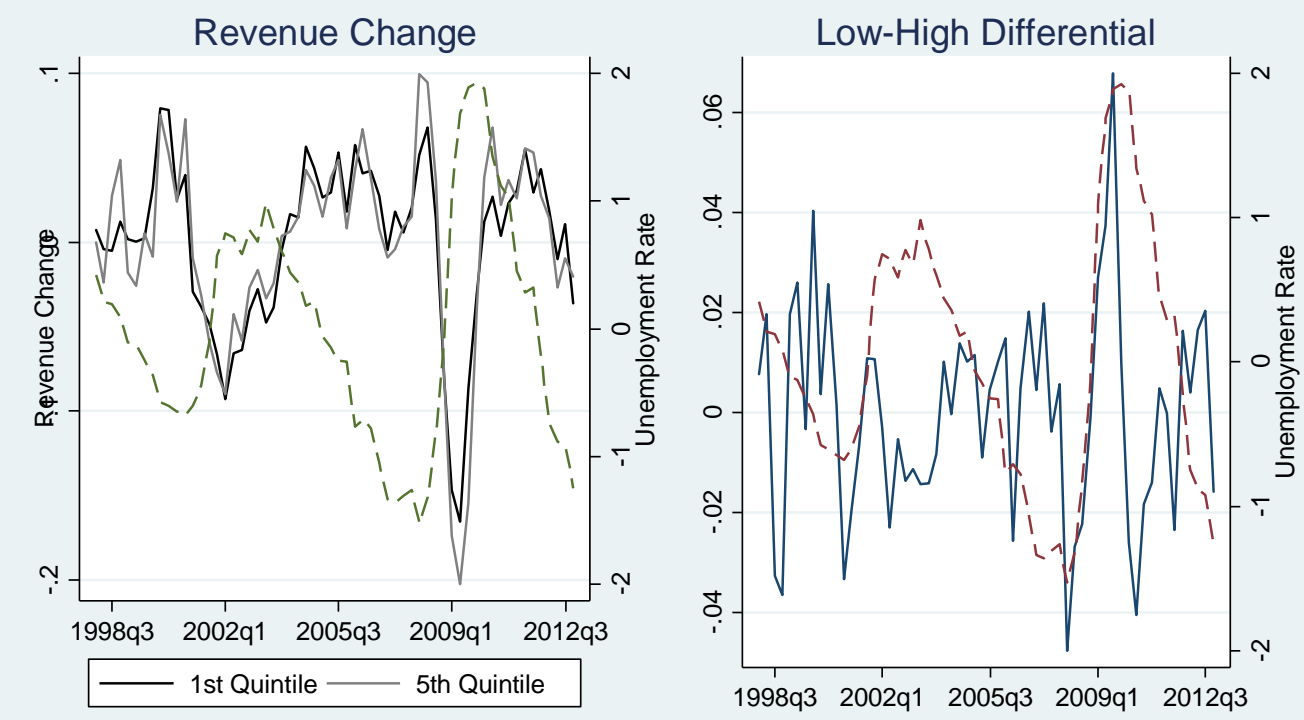

Date

HP Filtered and Seasonally Adjusted, Generated from Compustat Data Dashed Line = Unemployment Rate (left axis)

Figure 7: Downward Earnings Rigidity by Firm Pay Quintile
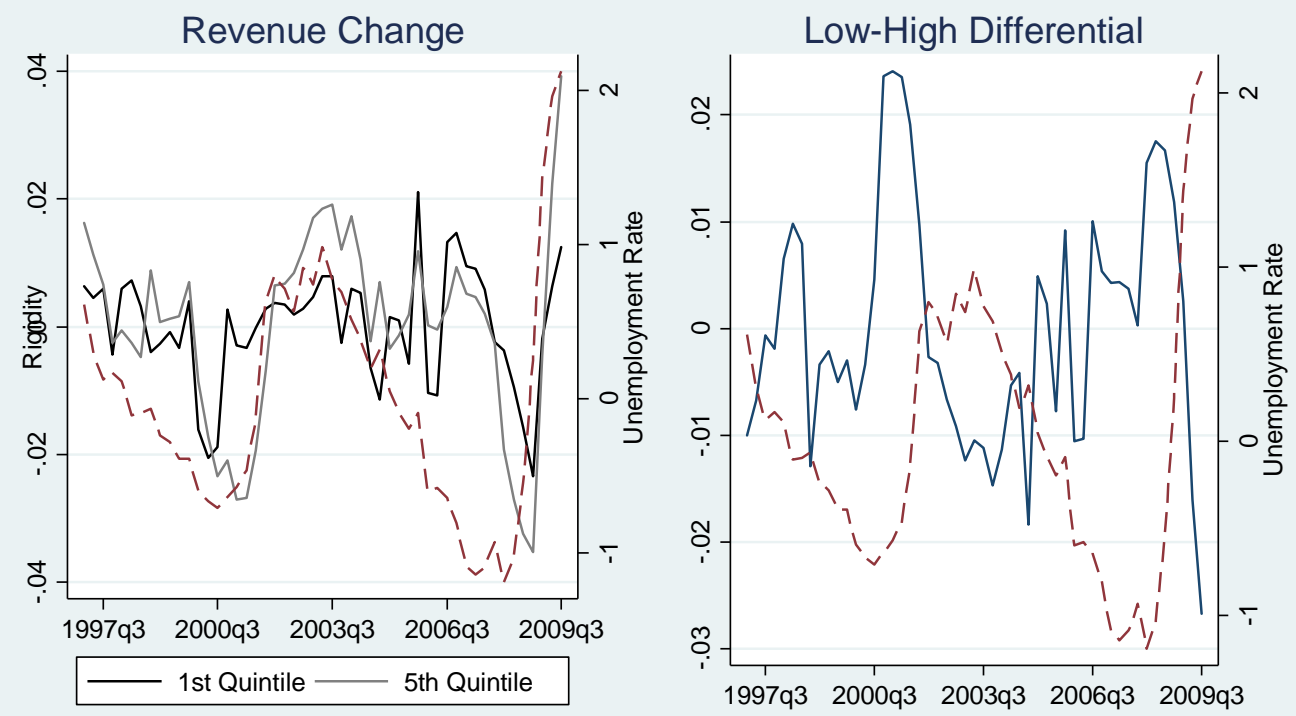

Date

HP Filtered and Seasonally Adjusted

Dashed Line = Unemployment Rate (left axis) 
Table 1: Summary Statistics by Pay Quintile

\begin{tabular}{|c|c|c|c|c|c|}
\hline & \multicolumn{5}{|c|}{ Wage Quintile } \\
\hline & Lowest & 2nd & $3 r d$ & 4th & Highest \\
\hline Growth Rate & 0.0017 & 0.0014 & 0.0017 & 0.0015 & 0.0030 \\
\hline Separation Rate & 0.203 & 0.158 & 0.130 & 0.117 & 0.107 \\
\hline Hire Rate & 0.205 & 0.160 & 0.132 & 0.118 & 0.110 \\
\hline Sep-to-Employment & 0.098 & 0.083 & 0.069 & 0.062 & 0.057 \\
\hline Sep-to-Non-Employment & 0.106 & 0.075 & 0.061 & 0.055 & 0.050 \\
\hline Hire-from-Employment & 0.092 & 0.081 & 0.070 & 0.065 & 0.063 \\
\hline Hire-from-Non-Employment & 0.113 & 0.079 & 0.062 & 0.054 & 0.047 \\
\hline State U Rate & 5.98 & 5.95 & 5.96 & 5.94 & 6.01 \\
\hline Average Monthly Earnings & $\$ 1,842.16$ & $\$ 2,754.87$ & $\$ 3,458.19$ & $\$ 4,354.70$ & $\$ 6,665.13$ \\
\hline \multicolumn{6}{|l|}{ Churn distribution: } \\
\hline Lowest & 0.103 & 0.132 & 0.195 & 0.248 & 0.299 \\
\hline 2nd & 0.117 & 0.170 & 0.222 & 0.253 & 0.235 \\
\hline $3 r d$ & 0.175 & 0.205 & 0.194 & 0.193 & 0.209 \\
\hline 4th & 0.239 & 0.228 & 0.213 & 0.154 & 0.155 \\
\hline Highest & 0.366 & 0.264 & 0.177 & 0.152 & 0.102 \\
\hline \multicolumn{6}{|l|}{ Size distribution: } \\
\hline$<20$ & 0.319 & 0.168 & 0.116 & 0.105 & 0.109 \\
\hline $20-50$ & 0.112 & 0.090 & 0.074 & 0.075 & 0.077 \\
\hline $50-250$ & 0.157 & 0.155 & 0.124 & 0.115 & 0.135 \\
\hline $250-500$ & 0.055 & 0.060 & 0.050 & 0.043 & 0.047 \\
\hline $500+$ & 0.358 & 0.526 & 0.637 & 0.662 & 0.632 \\
\hline
\end{tabular}

Notes: Weighted by average employment over the quarter. Quintile cutpoints are stateindustry (two-digit NAICS) specific. 
Table 2: Growth Rates as a Function of Economic Conditions and Firm Characteristics

\begin{tabular}{|c|c|c|c|c|c|c|c|}
\hline & $\mathbf{I}$ & II & III & IV & $\mathbf{V}$ & VI & VII \\
\hline \multicolumn{8}{|c|}{ Panel A: Regression Coefficients } \\
\hline \multirow[t]{2}{*}{ State Unemp Rate (U) } & -0.00002 & 0.00019 & 0.00018 & 0.00038 & -0.00038 & -0.00039 & 0.000002 \\
\hline & {$[0.00020]$} & {$[0.00036]$} & {$[0.00045]$} & {$[0.00036]$} & {$[0.00031]$} & {$[0.00034]$} & {$[0.00028]$} \\
\hline \multirow[t]{2}{*}{$U * 2$ nd pay quintile } & -0.00065 & -0.00064 & -0.00028 & -0.00077 & -0.00043 & -0.00018 & -0.00088 \\
\hline & {$[0.00006]^{* *}$} & {$[0.00006]^{* *}$} & {$[0.00033]$} & {$[0.00011]^{* *}$} & {$[0.00011]^{* *}$} & {$[0.00006]^{* *}$} & {$[0.00025]^{* *}$} \\
\hline \multirow[t]{2}{*}{$U * 3$ rd pay quintile } & -0.0011 & -0.0011 & -0.0006 & -0.0013 & -0.0007 & -0.0003 & -0.0012 \\
\hline & {$[0.00010]^{* *}$} & {$[0.00010]^{* *}$} & {$[0.00047]$} & {$[0.00013]^{* *}$} & {$[0.00014]^{* *}$} & {$[0.00007]^{* *}$} & {$[0.00026]^{* *}$} \\
\hline \multirow{2}{*}{$U * 4$ th pay quintile } & -0.0011 & -0.0011 & -0.0011 & -0.0013 & -0.0007 & -0.0002 & -0.0013 \\
\hline & {$[0.00011]^{* *}$} & {$[0.00011]^{* *}$} & {$[0.00045]^{*}$} & {$[0.00011]^{* *}$} & {$[0.00014]^{* *}$} & {$[0.0001]^{*}$} & {$[0.00025]^{* *}$} \\
\hline \multirow[t]{2}{*}{$U * 5$ th pay quintile } & -0.0011 & -0.0011 & -0.0011 & -0.0014 & -0.0006 & 0.00004 & -0.0012 \\
\hline & {$[0.00009]^{* *}$} & {$[0.00009]^{* *}$} & {$[0.00034]^{* *}$} & {$[0.00011]^{* *}$} & {$[0.00013]^{* *}$} & {$[0.00014]$} & {$[0.00024]^{* *}$} \\
\hline \multicolumn{8}{|c|}{ Panel B: Elasticities } \\
\hline 1st wage quintile & -0.06 & 0.65 & 0.61 & 0.85 & -1.57 & -0.96 & 0.006 \\
\hline 2nd wage quintile & -2.88 & -1.95 & -1.19 & -1.08 & -4.28 & -2.92 & -3.624 \\
\hline 3rd wage quintile & -3.96 & -3.20 & -2.25 & -4.51 & -5.17 & -3.72 & -4.885 \\
\hline 4th wage quintile & -4.41 & -3.52 & -4.46 & -3.86 & -5.28 & -5.18 & -4.705 \\
\hline 5th wage quintile & -2.20 & -1.78 & -2.16 & -3.36 & -2.35 & -1.25 & -2.144 \\
\hline Quarter fixed effects + time trend & $\mathrm{X}$ & & & & & & \\
\hline Date fixed effects & & $X$ & $x$ & $X$ & $X$ & $X$ & $X$ \\
\hline Fully interacted controls & & & $X$ & & & & \\
\hline Aggregate Cut-points & & & & $x$ & & & \\
\hline Excluding small firms & & & & & $X$ & & \\
\hline Firm Fixed Effects & & & & & & $X$ & \\
\hline Including non-primary jobs & & & & & & & $\mathrm{X}$ \\
\hline
\end{tabular}

+ significant at $10 \%$; significant at $5 \%$;* significant at $1 \%$

Notes: Regressions weighted by average employment over the quarter and control for quintile fixed effects, churn and size controls, and state and two-digit NAICS industry fixed effects. Unless otherwise specified, quintiles are obtained by averaging quarterly pay over the lifetime of the firm and fitting into the two-digit NAICS industry-state distribution weighted by employment. Standard errors in brackets are clustered at the state level. Coefficients from panel $A$ are converted to elasticities in panel $B$ by adding the main effect of $U$ to the relevant interaction term then multiplying and dividing by the quintile-specific average state unemployment rate and dependent variable, respectively. Column III estimates separate regressions for each quintile to allow all control variables to interact with quintile. Coeffients are then the total impact of the unemployment rate on the dependent variable (not a main effect and interactions). In column IV, quintiles are defined based on the overall disitribution of workers, not the state-industry distribution. Column $V$ excludes firms with fewer than 50 employees and uses this sample to generate quintile cutpoints. Column VI uses firm fixed effects instead of average firm pay (see text). In Column VII non-primary jobs (which have been excluded from the main analysis) are included. 
Table 3: Flow Rates as a Function of Economic Conditions and Firm

Growth Rate Separation Rate Hire Rate

\begin{tabular}{lc|c|c} 
& \multicolumn{1}{c}{ I } & II & III \\
\hline State Unemp Rate (U) & 0.00019 & -0.0028 & -0.0026 \\
& {$[0.00036]$} & {$[0.00086]^{* *}$} & {$[0.0003]^{* *}$} \\
$U^{*}$ 2nd pay quintile & -0.00064 & 0.0005 & -0.0001 \\
& {$[0.00006]^{* *}$} & {$[0.00017]^{* *}$} & {$[0.0002]$} \\
$U^{*}$ 3rd pay quintile & -0.0011 & 0.0012 & 0.0001 \\
& {$[0.00010]^{* *}$} & {$[0.00033]^{* *}$} & {$[0.0002]$} \\
$U^{*}$ 4th pay quintile & -0.0011 & 0.0022 & 0.0011 \\
& {$[0.00011]^{* *}$} & {$[0.00037]^{* *}$} & {$[0.0002]^{* *}$} \\
$U^{*}$ 5th pay quintile & -0.0011 & 0.0024 & 0.0013 \\
& {$[0.00009]^{* *}$} & {$[0.00036]^{* *}$} & {$[0.0002]^{* *}$} \\
\hline & Panel B: Elasticities & \\
\hline 1st wage quintile & 0.65 & -0.08 & -0.08 \\
2nd wage quintile & -1.95 & -0.08 & -0.10 \\
3rd wage quintile & -3.20 & -0.07 & -0.11 \\
4th wage quintile & -3.52 & -0.03 & -0.07 \\
5th wage quintile & -1.78 & -0.02 & -0.07 \\
\hline Date fixed effects & $\mathrm{X}$ & $\mathrm{X}$ & $\mathrm{X}$ \\
\hline
\end{tabular}

+ significant at $10 \% ;{ }^{*}$ significant at $5 \% ; * *$ significant at $1 \%$

Notes: See table 2 column II notes. 
Table 4: Flow Rates as a Function of Economic Conditions and Firm Characteristics

\begin{tabular}{|c|c|c|c|c|c|}
\hline \multirow{2}{*}{\multicolumn{2}{|c|}{$\begin{array}{c}\text { Growth Rate } \\
\text { I }\end{array}$}} & \multicolumn{2}{|c|}{ Separation Rates to: } & \multicolumn{2}{|c|}{ Hire Rates from: } \\
\hline & & $\begin{array}{l}\text { emp } \\
\text { II }\end{array}$ & $\begin{array}{c}\text { non-emp } \\
\text { III }\end{array}$ & $\begin{array}{l}\text { emp } \\
\text { IV }\end{array}$ & $\begin{array}{c}\text { non-emp } \\
\mathbf{V}\end{array}$ \\
\hline \multicolumn{6}{|c|}{ Panel A: Regression Coefficients } \\
\hline State Unemp Rate (U) & $\begin{array}{c}0.00019 \\
{[0.00036]}\end{array}$ & $\begin{array}{c}-0.0025 \\
{[0.00036]^{* *}}\end{array}$ & $\begin{array}{c}-0.00029 \\
{[0.00068]}\end{array}$ & $\begin{array}{c}-0.0024 \\
{[0.00048]^{* *}}\end{array}$ & $\begin{array}{c}-0.00021 \\
{[0.00054]}\end{array}$ \\
\hline$U * 2$ nd pay quintile & $\begin{array}{c}-0.00064 \\
{[0.00006]^{* *}}\end{array}$ & $\begin{array}{c}0.0002 \\
{[0.00013]}\end{array}$ & $\begin{array}{c}0.00033 \\
{[0.00013]^{*}}\end{array}$ & $\begin{array}{c}-0.0002 \\
{[0.00014]}\end{array}$ & $\begin{array}{c}0.00007 \\
{[0.00012]}\end{array}$ \\
\hline$U * 3$ rd pay quintile & $\begin{array}{c}-0.0011 \\
{[0.00010]^{* *}}\end{array}$ & $\begin{array}{c}0.0009 \\
{[0.00023]^{* *}}\end{array}$ & $\begin{array}{c}0.00037 \\
{[0.00018]^{*}}\end{array}$ & $\begin{array}{c}0.0001 \\
{[0.00018]}\end{array}$ & $\begin{array}{c}0.00007 \\
{[0.00017]}\end{array}$ \\
\hline$U * 4$ th pay quintile & $\begin{array}{c}-0.0011 \\
{[0.00011]^{* *}}\end{array}$ & $\begin{array}{c}0.0016 \\
{[0.00027]^{* *}}\end{array}$ & $\begin{array}{c}0.00056 \\
{[0.00012]^{*}}\end{array}$ & $\begin{array}{c}0.0007 \\
{[0.00025]^{* *}}\end{array}$ & $\begin{array}{c}0.00040 \\
{[0.00020]+}\end{array}$ \\
\hline$U * 5$ th pay quintile & $\begin{array}{c}-0.0011 \\
{[0.00009]^{* *}}\end{array}$ & $\begin{array}{c}0.0018 \\
{[0.00026]^{* *}}\end{array}$ & $\begin{array}{c}0.00053 \\
{[0.00024]^{*}} \\
\end{array}$ & $\begin{array}{c}0.0009 \\
{[0.00027]^{* *}}\end{array}$ & $\begin{array}{c}0.00041 \\
{[0.00021]+}\end{array}$ \\
\hline \multicolumn{6}{|c|}{ Panel B: Elasticities } \\
\hline 1st wage quintile & 0.65 & -0.15 & -0.016 & -0.15 & -0.011 \\
\hline 2nd wage quintile & -1.95 & -0.16 & 0.003 & -0.19 & -0.010 \\
\hline 3rd wage quintile & -3.20 & -0.14 & 0.007 & -0.20 & -0.013 \\
\hline 4th wage quintile & -3.52 & -0.08 & 0.030 & -0.15 & 0.021 \\
\hline 5th wage quintile & -1.78 & -0.07 & 0.029 & -0.14 & 0.027 \\
\hline Date fixed effects & $x$ & $x$ & $x$ & $x$ & $x$ \\
\hline
\end{tabular}

+ significant at $10 \% ;{ }^{*}$ significant at $5 \% ;{ }^{* *}$ significant at $1 \%$

Notes: See table 2 column II notes. 
Table 5: Worker Reallocation over the Business Cycle

\begin{tabular}{|c|c|c|c|c|c|c|c|c|c|c|c|}
\hline \multicolumn{6}{|c|}{ Transistion Matrix in Boom } & \multicolumn{6}{|c|}{ Transistion Matrix in Bust } \\
\hline \multirow[t]{2}{*}{ in $t+1:$} & \multicolumn{5}{|c|}{ firm in $\mathrm{t}$ : } & \multirow[t]{2}{*}{ firm in $t+1:$} & \multicolumn{5}{|c|}{ firm in $\mathrm{t}:$} \\
\hline & 1 & 2 & 3 & 4 & 5 & & 1 & 2 & 3 & 4 & 5 \\
\hline 5 & 0.000 & 0.000 & 0.002 & 0.077 & 0.940 & 5 & 0.000 & 0.000 & 0.002 & 0.080 & 0.938 \\
\hline 4 & 0.000 & 0.005 & 0.125 & 0.777 & 0.059 & 4 & 0.000 & 0.005 & 0.127 & 0.779 & 0.061 \\
\hline 3 & 0.003 & 0.131 & 0.696 & 0.140 & 0.001 & 3 & 0.002 & 0.130 & 0.697 & 0.136 & 0.001 \\
\hline 2 & 0.098 & 0.721 & 0.171 & 0.005 & 0.000 & 2 & 0.078 & 0.721 & 0.168 & 0.005 & 0.000 \\
\hline 1 & 0.899 & 0.144 & 0.006 & 0.000 & 0.000 & 1 & 0.920 & 0.144 & 0.005 & 0.000 & 0.000 \\
\hline$t+1:$ & $\$ 1,936$ & $\$ 2,724$ & $\$ 3,447$ & $\$ 4,399$ & $\$ 6,527$ & & $\$ 1,917$ & $\$ 2,723$ & $\$ 3,452$ & $\$ 4,409$ & $\$ 6,520$ \\
\hline
\end{tabular}

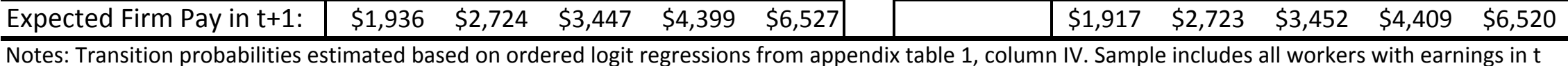
and $t+1$. A boom is a $4.2 \%$ unemployment rate and a bust is a $10.4 \%$ unemployment rate. 
Table 6: Firm Quality of New Matches over the Business Cycle

\begin{tabular}{rr|cc} 
firm in t: & Boom & Bust \\
\hline 5 & 0.046 & 0.039 \\
4 & 0.081 & 0.071 \\
3 & 0.146 & 0.133 \\
2 & 0.304 & 0.296 \\
& 1 & 0.422 & 0.461 \\
\hline Expected Firm Pay: & $\$ 2,782$ & $\$ 2,695$ \\
\hline \multicolumn{2}{l|}{ Notes: Estimates based on ordered logit regressions from }
\end{tabular}
appendix table 2, column IV. Sample includes all workers who matched to firms in $\mathrm{t}$. A boom is a $4.2 \%$ unemployment rate and a bust is a $10.4 \%$ unemployment rate. 
Table 7: Worker Reallocation for New Matches over the Business Cycle

\section{Transistion Matrix in Boom}

\begin{tabular}{r|ccccc} 
firm in t+3: & \multicolumn{7}{c}{ firm in t: } \\
& 1 & 2 & 3 & 4 & 5 \\
5 & 0.010 & 0.031 & 0.072 & 0.181 & 0.650 \\
4 & 0.036 & 0.099 & 0.194 & 0.326 & 0.246 \\
3 & 0.088 & 0.192 & 0.269 & 0.258 & 0.069 \\
2 & 0.241 & 0.325 & 0.281 & 0.161 & 0.026 \\
1 & 0.625 & 0.352 & 0.184 & 0.074 & 0.009 \\
\hline Expected Firm Pay in $\mathrm{t}+3:$ & $\$ 2,346$ & $\$ 2,849$ & $\$ 3,369$ & $\$ 4,097$ & $\$ 5,730$ \\
\hline
\end{tabular}

\section{Transistion Matrix in Bust}

\begin{tabular}{|r|rcccc}
\multicolumn{6}{|c}{ Transistion Matrix in Bust } \\
& 1 & 2 & 3 & 4 & 5 \\
5 & 0.010 & 0.032 & 0.073 & 0.176 & 0.575 \\
4 & 0.034 & 0.101 & 0.194 & 0.322 & 0.288 \\
3 & 0.084 & 0.194 & 0.269 & 0.261 & 0.089 \\
2 & 0.234 & 0.325 & 0.281 & 0.165 & 0.035 \\
1 & 0.638 & 0.348 & 0.183 & 0.076 & 0.013 \\
\hline & $\$ 2,325$ & $\$ 2,859$ & $\$ 3,372$ & $\$ 4,071$ & $\$ 5,515$ \\
\hline
\end{tabular}

Notes: Transition probabilities estimated based on ordered logit regressions from appendix table 3, column IV. Sample includes all workers who matched to

firms in $\mathrm{t}$, with earnings in $\mathrm{t}+3$. A boom is a $4.2 \%$ unemployment rate and a bust is a $10.4 \%$ unemployment rate. 
Appendix Table 1: Separation Rates as a Function of Economic Conditions and Firm Characteristics

\begin{tabular}{|c|c|c|c|c|c|c|c|}
\hline & 1 & II & III & IV & $\mathbf{V}$ & VI & VII \\
\hline \multicolumn{8}{|c|}{ Panel A: Regression Coefficients } \\
\hline State Unemp Rate (U) & $\begin{array}{c}-0.0041 \\
{[0.00033]^{* *}}\end{array}$ & $\begin{array}{c}-0.0028 \\
{[0.00086]^{* *}}\end{array}$ & $\begin{array}{c}-0.0026 \\
{[0.0012]^{*}}\end{array}$ & $\begin{array}{c}-0.0051 \\
{[0.00093]^{* *}}\end{array}$ & $\begin{array}{c}-0.0033 \\
{[0.00084]^{* *}}\end{array}$ & $\begin{array}{c}-0.0018 \\
{[0.00077]^{*}}\end{array}$ & $\begin{array}{c}-0.0080 \\
{[0.00040]^{* *}}\end{array}$ \\
\hline$U * 2$ nd pay quintile & $\begin{array}{c}0.0005 \\
{[0.00017]^{* *}}\end{array}$ & $\begin{array}{c}0.0005 \\
{[0.00017]^{* *}}\end{array}$ & $\begin{array}{c}-0.0023 \\
{[0.0010]^{*}}\end{array}$ & $\begin{array}{c}0.0029 \\
{[0.00040]^{* *}}\end{array}$ & $\begin{array}{c}0.0009 \\
{[0.00018]^{* *}}\end{array}$ & $\begin{array}{c}-0.0004 \\
{[0.00019]^{*}}\end{array}$ & $\begin{array}{c}0.0026 \\
{[0.00036]^{* *}}\end{array}$ \\
\hline $\mathrm{U} * 3$ rd pay quintile & $\begin{array}{c}0.0012 \\
{[0.00033]^{* *}}\end{array}$ & $\begin{array}{c}0.0012 \\
{[0.00033]^{* *}}\end{array}$ & $\begin{array}{c}-0.0019 \\
{[0.00062]^{* *}}\end{array}$ & $\begin{array}{c}0.0046 \\
{[0.00057]^{* *}}\end{array}$ & $\begin{array}{c}0.0017 \\
{[0.00043]^{* *}}\end{array}$ & $\begin{array}{c}0.0001 \\
{[0.00024]}\end{array}$ & $\begin{array}{c}0.0052 \\
{[0.00035]^{* *}}\end{array}$ \\
\hline $\mathrm{U} * 4$ th pay quintile & $\begin{array}{c}0.0022 \\
{[0.00037]^{* *}}\end{array}$ & $\begin{array}{c}0.0022 \\
{[0.00037]^{* *}}\end{array}$ & $\begin{array}{c}-0.0004 \\
{[0.00063]}\end{array}$ & $\begin{array}{c}0.0048 \\
{[0.00049]^{* *}}\end{array}$ & $\begin{array}{c}0.0026 \\
{[0.00045]^{* *}}\end{array}$ & $\begin{array}{c}0.0010 \\
{[0.00033]^{* *}}\end{array}$ & $\begin{array}{c}0.0070 \\
{[0.00035]^{* *}}\end{array}$ \\
\hline$U * 5$ th pay quintile & $\begin{array}{c}0.0024 \\
{[0.00036]^{* *}}\end{array}$ & $\begin{array}{c}0.0024 \\
{[0.00036]^{* *}}\end{array}$ & $\begin{array}{c}-0.0007 \\
{[0.00077]}\end{array}$ & $\begin{array}{c}0.0052 \\
{[0.00058]^{* *}}\end{array}$ & $\begin{array}{c}0.0029 \\
{[0.00045]^{* *}}\end{array}$ & $\begin{array}{c}0.0010 \\
{[0.00039]^{*}}\end{array}$ & $\begin{array}{c}0.0077 \\
{[0.00033]^{* *}}\end{array}$ \\
\hline \multicolumn{8}{|c|}{ Panel B: Elasticities } \\
\hline 1st wage quintile & -0.12 & -0.08 & -0.08 & -0.12 & -0.10 & -0.06 & -0.16 \\
\hline 2nd wage quintile & -0.13 & -0.08 & -0.09 & -0.08 & -0.10 & -0.08 & -0.14 \\
\hline 3rd wage quintile & -0.13 & -0.07 & -0.09 & -0.02 & -0.08 & -0.08 & -0.09 \\
\hline 4th wage quintile & -0.10 & -0.03 & -0.02 & -0.02 & -0.04 & -0.04 & -0.04 \\
\hline 5th wage quintile & -0.10 & -0.02 & -0.04 & 0.01 & -0.02 & -0.04 & -0.01 \\
\hline $\begin{array}{l}\text { Quarter fixed effects + time trend } \\
\text { Date fixed effects }\end{array}$ & $x$ & $x$ & $x$ & $x$ & $x$ & $x$ & $x$ \\
\hline Fully interacted controls & & & $x$ & & & & \\
\hline Aggregate Cut-points & & & & $x$ & & & \\
\hline Excluding small firms & & & & & $x$ & & \\
\hline Firm Fixed Effects & & & & & & $x$ & \\
\hline Including non-primary jobs & & & & & & & $x$ \\
\hline
\end{tabular}

+ significant at $10 \%{ }^{*}$ significant at $5 \% ;{ }^{* *}$ significant at $1 \%$

Notes: See table 2. Each coefficient in column III panel A is from a separate regression and reflects the total impact of the unemployment rate on the separation rate for a given quintile, not a main effect and interactions. 
Appendix Table 2: Hire Rates as a Function of Economic Conditions and Firm Characteristics

\begin{tabular}{|c|c|c|c|c|c|c|c|}
\hline & I & II & III & IV & V & VI & VII \\
\hline \multicolumn{8}{|c|}{ Panel A: Regression Coefficients } \\
\hline \multirow[t]{2}{*}{ State Unemp Rate (U) } & -0.0041 & -0.0026 & -0.0024 & -0.0047 & -0.0036 & -0.0022 & -0.0080 \\
\hline & {$[0.0002]^{* *}$} & {$[0.0003]^{* *}$} & {$[0.00098]^{*}$} & {$[0.00094]^{* *}$} & {$[0.00087]^{* *}$} & {$[0.00084]^{*}$} & {$[0.00042]^{* *}$} \\
\hline \multirow[t]{2}{*}{$U * 2$ nd pay quintile } & -0.0001 & -0.0001 & -0.0026 & 0.0021 & 0.0005 & -0.0006 & 0.0017 \\
\hline & {$[0.0003]$} & {$[0.0002]$} & {$[0.00093]^{* *}$} & {$[0.00031]^{* *}$} & {$[0.00021]^{*}$} & {$[0.00021]^{* *}$} & {$[0.00038]^{* *}$} \\
\hline \multirow[t]{2}{*}{$\mathrm{U} *$ 3rd pay quintile } & 0.0001 & 0.0001 & -0.0025 & 0.0033 & 0.0011 & -0.0002 & 0.0041 \\
\hline & [0.0003] & {$[0.0002]$} & {$[0.00080]^{* *}$} & {$[0.00047]^{* *}$} & {$[0.00035]^{* *}$} & [0.00023] & {$[0.00036]^{* *}$} \\
\hline \multirow[t]{2}{*}{$\mathrm{U} * 4$ th pay quintile } & 0.0011 & 0.0011 & -0.0015 & 0.0034 & 0.0019 & 0.0008 & 0.0057 \\
\hline & {$[0.0002]^{* *}$} & {$[0.0002]^{* *}$} & {$[0.00069]^{*}$} & {$[0.00044]^{* *}$} & {$[0.00043]^{* *}$} & {$[0.00032]^{*}$} & {$[0.00036]^{* *}$} \\
\hline \multirow[t]{2}{*}{$U * 5$ th pay quintile } & 0.0013 & 0.0013 & -0.0017 & 0.0038 & 0.0023 & 0.0011 & 0.0065 \\
\hline & {$[0.0003]^{* *}$} & {$[0.0002]^{* *}$} & {$[0.00071]^{*}$} & {$[0.00051]^{* *}$} & {$[0.00041]^{* *}$} & {$[0.00042]^{*}$} & {$[0.00036]^{* *}$} \\
\hline \multicolumn{8}{|c|}{ Panel B: Elasticities } \\
\hline 1st wage quintile & -0.12 & -0.08 & -0.07 & -0.11 & -0.12 & -0.07 & -0.16 \\
\hline 2nd wage quintile & -0.16 & -0.10 & -0.10 & -0.09 & -0.13 & -0.11 & -0.16 \\
\hline $3 r d$ wage quintile & -0.18 & -0.11 & -0.11 & -0.07 & -0.13 & -0.11 & -0.13 \\
\hline 4th wage quintile & -0.15 & -0.07 & -0.08 & -0.08 & -0.09 & -0.07 & -0.09 \\
\hline 5th wage quintile & -0.15 & -0.07 & -0.10 & -0.06 & -0.08 & -0.06 & -0.06 \\
\hline Quarter fixed effects + time trend & $x$ & & & & & & \\
\hline Date fixed effects & & $x$ & $x$ & $X$ & $x$ & $x$ & $x$ \\
\hline Fully interacted controls & & & $x$ & & & & \\
\hline Aggregate Cut-points & & & & $x$ & & & \\
\hline Excluding small firms & & & & & $\mathrm{x}$ & & \\
\hline Firm Fixed Effects & & & & & & $x$ & \\
\hline Including non-primary jobs & & & & & & & $x$ \\
\hline
\end{tabular}

+ significant at $10 \%$; ${ }^{*}$ significant at $5 \%$; ${ }^{* *}$ significant at $1 \%$

Notes: See table 2. Each coefficient in column III panel A is from a separate regression and reflects the total impact of the unemployment rate on the hire rate for a given quintile, not a main effect and interactions. 
Appendix Table 3: Separation-to-Employment Rates as a Function of Economic Conditions and Firm Characteristics

\begin{tabular}{|c|c|c|c|c|c|c|}
\hline & I & II & III & IV & V & VI \\
\hline \multicolumn{7}{|c|}{ Panel A: Regression Coefficients } \\
\hline \multirow[t]{2}{*}{ State Unemp Rate (U) } & -0.0042 & -0.0025 & -0.0024 & -0.0042 & -0.0030 & -0.0021 \\
\hline & {$[0.00024]^{* *}$} & {$[0.00036]^{* *}$} & {$[0.00049]^{* *}$} & {$[0.00046]^{* *}$} & {$[0.00030]^{* *}$} & {$[0.00030]^{* *}$} \\
\hline \multirow[t]{2}{*}{$U * 2$ nd pay quintile } & 0.0002 & 0.0002 & -0.0022 & 0.0020 & 0.0007 & -0.0001 \\
\hline & {$[0.00013]$} & [0.00013] & {$[0.00036]^{* *}$} & {$[0.00037]^{* *}$} & {$[0.00008]^{* *}$} & {$[0.00011]$} \\
\hline \multirow[t]{2}{*}{$U * 3 r d$ pay quintile } & 0.0009 & 0.0009 & -0.0017 & 0.0033 & 0.0014 & 0.0003 \\
\hline & {$[0.00023]^{* *}$} & {$[0.00023]^{* *}$} & {$[0.00025]^{* *}$} & {$[0.00046]^{* *}$} & {$[0.00031]^{* *}$} & {$[0.00016]+$} \\
\hline \multirow[t]{2}{*}{$U * 4$ th pay quintile } & 0.0016 & 0.0016 & -0.0009 & 0.0037 & 0.0022 & 0.0011 \\
\hline & {$[0.00027]^{* *}$} & {$[0.00027]^{* *}$} & {$[0.00030]^{* *}$} & {$[0.00040]^{* *}$} & {$[0.00031]^{* *}$} & {$[0.00015]^{* *}$} \\
\hline \multirow[t]{2}{*}{$U * 5$ th pay quintile } & 0.0018 & 0.0018 & -0.0009 & 0.0039 & 0.0024 & 0.0014 \\
\hline & {$[0.00026]^{* *}$} & {$[0.00026]^{* *}$} & {$[0.00022]^{* *}$} & {$\left[0.00047^{\prime * *}\right.$} & {$[0.00035]^{* *}$} & {$[0.00019]^{* *}$} \\
\hline
\end{tabular}

\begin{tabular}{|c|c|c|c|c|c|c|}
\hline \multicolumn{7}{|c|}{ Panel B: Elasticities } \\
\hline 1st wage quintile & -0.26 & -0.15 & -0.15 & -0.19 & -0.18 & -0.13 \\
\hline 2nd wage quintile & -0.29 & -0.16 & -0.16 & -0.15 & -0.17 & -0.16 \\
\hline 3rd wage quintile & -0.29 & -0.14 & -0.14 & -0.09 & -0.15 & -0.15 \\
\hline 4th wage quintile & -0.25 & -0.08 & -0.08 & -0.06 & -0.08 & -0.10 \\
\hline 5th wage quintile & -0.25 & -0.07 & -0.10 & -0.04 & -0.07 & -0.07 \\
\hline Quarter fixed effects + time trend & $\mathrm{X}$ & & & & & \\
\hline Date fixed effects & & $\mathrm{X}$ & $\mathrm{X}$ & $\mathrm{X}$ & $\mathrm{X}$ & $x$ \\
\hline Fully interacted controls & & & $x$ & & & \\
\hline Aggregate Cut-points & & & & $\mathrm{x}$ & & \\
\hline Excluding small firms & & & & & $\mathrm{x}$ & \\
\hline Firm Fixed Effects & & & & & & $x$ \\
\hline
\end{tabular}

+ significant at $10 \%{ }^{*}$ significant at $5 \%{ }^{* *}$ significant at $1 \%$

Notes: See table 2. A separation is classified as "to employment" if the worker transitions without experiencing a full quarter with no earnings (see text). Each coefficient in column III panel A is from a separate regression and reflects the total impact of the unemployment rate on the separation rate for a given quintile, not a main effect and interactions. 
Appendix Table 4: Separation-to-Nonemployment Rates as a Function of Economic Conditions and Firm

\begin{tabular}{|c|c|c|c|c|c|c|}
\hline & $\mathbf{I}$ & II & III & IV & V & VI \\
\hline \multicolumn{7}{|c|}{ Panel A: Regression Coefficients } \\
\hline \multirow[t]{2}{*}{ State Unemp Rate (U) } & 0.00010 & -0.00029 & -0.00017 & -0.00087 & -0.00024 & 0.00030 \\
\hline & {$[0.00027]$} & {$[0.00068]$} & {$[0.00086]$} & {$[0.00070]$} & {$[0.00067]$} & {$[0.00064]$} \\
\hline \multirow[t]{2}{*}{$U * 2$ nd pay quintile } & 0.00034 & 0.00033 & -0.00013 & 0.00088 & 0.00019 & -0.00038 \\
\hline & {$[0.00013]^{*}$} & {$[0.00013]^{*}$} & {$[0.00074]$} & {$[0.00016]^{* *}$} & {$[0.00013]$} & {$[0.00017]^{*}$} \\
\hline \multirow[t]{2}{*}{$\mathrm{U} *$ 3rd pay quintile } & 0.00037 & 0.00037 & -0.00024 & 0.00124 & 0.00032 & -0.00018 \\
\hline & {$[0.00018]^{*}$} & {$[0.00018]^{*}$} & {$[0.00062]$} & {$[0.00023]^{* *}$} & {$[0.00017]+$} & {$[0.00017]$} \\
\hline \multirow[t]{2}{*}{$U * 4$ th pay quintile } & 0.00058 & 0.00056 & 0.00045 & 0.00112 & 0.00034 & -0.00008 \\
\hline & {$[0.00022]^{*}$} & {$[0.00012]^{*}$} & {$[0.00062]$} & {$[0.00026]^{* *}$} & {$[0.00022]$} & {$[0.00021]$} \\
\hline \multirow[t]{2}{*}{$U * 5$ th pay quintile } & 0.00052 & 0.00053 & 0.00025 & 0.00131 & 0.00051 & -0.00041 \\
\hline & {$[0.00024]^{*}$} & {$[0.00024]^{*}$} & {$[0.00070]$} & {$[0.00034]^{* *}$} & {$[0.00025]+$} & {$[0.00026]$} \\
\hline \multicolumn{7}{|c|}{ Panel B: Elasticities } \\
\hline 1st wage quintile & 0.006 & -0.016 & -0.010 & -0.042 & -0.016 & 0.018 \\
\hline 2nd wage quintile & 0.035 & 0.003 & -0.011 & 0.001 & -0.005 & -0.006 \\
\hline 3rd wage quintile & 0.047 & 0.007 & -0.023 & 0.038 & 0.008 & 0.012 \\
\hline 4th wage quintile & 0.073 & 0.030 & 0.049 & 0.031 & 0.012 & 0.024 \\
\hline 5th wage quintile & 0.076 & 0.029 & 0.030 & 0.067 & 0.035 & -0.011 \\
\hline Quarter fixed effects + time trend & $x$ & & & & & \\
\hline Date fixed effects & & $\mathrm{x}$ & $x$ & $x$ & $x$ & $x$ \\
\hline Fully interacted controls & & & $x$ & & & \\
\hline Aggregate Cut-points & & & & $x$ & & \\
\hline Excluding small firms & & & & & $x$ & \\
\hline Firm Fixed Effects & & & & & & $x$ \\
\hline
\end{tabular}

+ significant at $10 \%$; ${ }^{*}$ significant at $5 \%$; ${ }^{* *}$ significant at $1 \%$

Notes: See table 2. A separation is classified as "to non-employment" if the worker transitions and experiences a full quarter with no earnings (see text). Each coefficient in column III panel A is from a separate regression and reflects the total impact of the unemployment rate on the separation rate for a given quintile, not a main effect and interactions. 
Appendix Table 5: Hire-from-Employment Rates as a Function of Economic Conditions and Firm Characteristics

\begin{tabular}{|c|c|c|c|c|c|c|}
\hline & $\mathbf{I}$ & II & III & IV & $\mathbf{v}$ & VI \\
\hline \multicolumn{7}{|c|}{ Panel A: Regression Coefficients } \\
\hline \multirow[t]{2}{*}{ State Unemp Rate (U) } & -0.0038 & -0.0024 & -0.0024 & -0.0037 & -0.0031 & -0.0023 \\
\hline & {$[0.00031]^{* *}$} & {$[0.00048]^{* *}$} & {$[0.00055]^{* *}$} & {$[0.00057]^{* *}$} & {$[0.00046]^{* *}$} & {$[0.00043]^{* *}$} \\
\hline \multirow[t]{2}{*}{$U * 2$ nd pay quintile } & -0.0002 & -0.0002 & -0.0024 & 0.0012 & 0.0004 & -0.0002 \\
\hline & {$[0.00014]$} & {$[0.00014]$} & {$[0.00041]^{* *}$} & {$[0.00033]^{* *}$} & {$[0.00011]^{* *}$} & {$[0.000096]^{*}$} \\
\hline \multirow[t]{2}{*}{$U^{*} 3 r d$ pay quintile } & 0.0001 & 0.0001 & -0.0022 & 0.0022 & 0.0008 & -0.000004 \\
\hline & {$[0.00018]$} & {$[0.00018]$} & {$[0.00039]^{* *}$} & {$[0.00040]^{* *}$} & {$[0.00023]^{* *}$} & {$[0.00014]$} \\
\hline \multirow[t]{2}{*}{$\mathrm{U} * 4$ th pay quintile } & 0.0007 & 0.0007 & -0.0017 & 0.0023 & 0.0014 & 0.0007 \\
\hline & {$[0.00025]^{* *}$} & {$[0.00025]^{* *}$} & {$[0.00028]^{* *}$} & {$[0.00038]^{* *}$} & {$[0.00032]^{* *}$} & {$[0.00013]^{* *}$} \\
\hline \multirow[t]{2}{*}{$U * 5$ th pay quintile } & 0.0009 & 0.0009 & -0.0018 & 0.0026 & 0.0016 & 0.0010 \\
\hline & {$[0.00027]^{* *}$} & {$[0.00027]^{* *}$} & {$[0.00037]^{* *}$} & {$[0.00043]^{* *}$} & {$[0.00034]^{* *}$} & {$[0.00023]^{* *}$} \\
\hline \multicolumn{7}{|c|}{ Panel B: Elasticities } \\
\hline 1st wage quintile & -0.25 & -0.15 & -0.15 & -0.19 & -0.20 & -0.15 \\
\hline 2nd wage quintile & -0.30 & -0.19 & -0.17 & -0.18 & -0.21 & -0.18 \\
\hline 3rd wage quintile & -0.32 & -0.20 & -0.19 & -0.15 & -0.21 & -0.19 \\
\hline 4th wage quintile & -0.29 & -0.15 & -0.16 & -0.15 & -0.16 & -0.15 \\
\hline 5th wage quintile & -0.28 & -0.14 & -0.17 & -0.14 & -0.15 & -0.12 \\
\hline Quarter fixed effects + time trend & $\mathrm{X}$ & & & & & \\
\hline Date fixed effects & & $x$ & $x$ & $x$ & $X$ & $x$ \\
\hline Fully interacted controls & & & $x$ & & & \\
\hline Aggregate Cut-points & & & & $x$ & & \\
\hline Excluding small firms & & & & & $x$ & \\
\hline Firm Fixed Effects & & & & & & $x$ \\
\hline
\end{tabular}

+ significant at $10 \%$; ${ }^{*}$ significant at $5 \%$; ${ }^{* *}$ significant at $1 \%$

Notes: See table 2. A separation is classified as "from employment" if the worker transitions without experiencing a full quarter with no earnings (see text). Each coefficient in column III panel A is from a separate regression and reflects the total impact of the unemployment rate on the hire rate for a given quintile, not a main effect and interactions. 
Appendix Table 6: Hires-from-Nonemployment Rates as a Function of Economic Conditions and Firm

\begin{tabular}{|c|c|c|c|c|c|c|}
\hline & I & II & III & IV & V & VI \\
\hline \multicolumn{7}{|c|}{ Panel A: Regression Coefficients } \\
\hline \multirow[t]{2}{*}{ State Unemp Rate (U) } & -0.00029 & -0.00021 & -0.00003 & -0.00375 & -0.00052 & 0.00010 \\
\hline & {$[0.00028]$} & {$[0.00054]$} & {$[0.00064]$} & {$[0.00057]^{* *}$} & {$[0.00053]$} & {$[0.00055]$} \\
\hline \multirow[t]{2}{*}{$U * 2$ nd pay quintile } & 0.00007 & 0.00007 & -0.00020 & 0.00120 & 0.00010 & -0.00041 \\
\hline & {$[0.00012]$} & {$[0.00012]$} & {$[0.00060]$} & {$[0.00033]^{* *}$} & {$[0.00016]$} & {$[0.00018]^{*}$} \\
\hline \multirow[t]{2}{*}{$\mathrm{U} * 3$ rd pay quintile } & 0.00006 & 0.00007 & -0.00034 & 0.00215 & 0.00030 & -0.00019 \\
\hline & {$[0.00017]$} & {$[0.00017]$} & {$[0.00051]$} & {$[0.00040]^{* *}$} & {$[0.00020]$} & [0.00018] \\
\hline \multirow[t]{2}{*}{$\mathrm{U} * 4$ th pay quintile } & 0.00039 & 0.00040 & 0.00017 & 0.00233 & 0.00045 & 0.00010 \\
\hline & {$[0.00020]+$} & {$[0.00020]+$} & {$[0.00058]$} & {$[0.00038]^{* *}$} & {$[0.00021]^{*}$} & [0.00024] \\
\hline \multirow[t]{2}{*}{$U * 5$ th pay quintile } & 0.00041 & 0.00041 & 0.00007 & 0.00260 & 0.00064 & 0.00001 \\
\hline & {$[0.00020]+$} & {$[0.00021]+$} & {$[0.00056]$} & {$[0.00043]^{* *}$} & {$[0.00022]^{* *}$} & [0.00029] \\
\hline \multicolumn{7}{|c|}{ Panel B: Elasticities } \\
\hline 1st wage quintile & -0.016 & -0.011 & -0.002 & -0.040 & -0.032 & 0.005 \\
\hline 2nd wage quintile & -0.017 & -0.010 & -0.015 & -0.001 & -0.037 & -0.023 \\
\hline 3rd wage quintile & -0.023 & -0.013 & -0.032 & 0.025 & -0.025 & -0.008 \\
\hline 4th wage quintile & 0.010 & 0.021 & 0.019 & 0.023 & -0.008 & 0.022 \\
\hline 5th wage quintile & 0.015 & 0.027 & 0.008 & 0.053 & 0.016 & 0.012 \\
\hline Quarter fixed effects + time trend & $x$ & & & & & \\
\hline Date fixed effects & & $x$ & $x$ & $x$ & $x$ & $x$ \\
\hline Fully interacted controls & & & $x$ & & & \\
\hline Aggregate Cut-points & & & & $\mathrm{x}$ & & \\
\hline Excluding small firms & & & & & $x$ & \\
\hline Firm Fixed Effects & & & & & & $x$ \\
\hline
\end{tabular}

+ significant at $10 \%$; $^{*}$ significant at $5 \%$; $^{* *}$ significant at $1 \%$

Notes: See table 2. A hire is classified as "from non-employment" if the worker transitions and experiences a full quarter with no earnings (see text). Each coefficient in column III panel $\mathrm{A}$ is from a separate regression and reflects the total impact of the unemployment rate on the hire rate for a given quintile, not a main effect and interactions. 
Appendix Table 7: Worker Reallocation over the Business Cycle

Dependent variable: Firm pay quintile in $\mathrm{t}+1$

\begin{tabular}{|c|c|c|c|c|}
\hline & I & II & III & IV \\
\hline \multirow[t]{2}{*}{ State Unemp Rate (U) } & -0.0429 & -0.0423 & -0.0392 & -0.0403 \\
\hline & {$[0.0053]^{* *}$} & {$[0.0054]^{* *}$} & {$[0.0047]^{* *}$} & {$[0.0049]^{* *}$} \\
\hline \multirow[t]{2}{*}{$U * 2$ nd pay quintile } & 0.0401 & 0.0397 & 0.0403 & 0.0399 \\
\hline & {$[0.0064]^{* *}$} & {$[0.0064]^{* *}$} & {$[0.0064]^{* *}$} & {$[0.0064]^{* *}$} \\
\hline \multirow[t]{2}{*}{$U * 3 r d$ pay quintile } & 0.0440 & 0.0433 & 0.0444 & 0.0438 \\
\hline & {$[0.0077]^{* *}$} & {$[0.0075]^{* *}$} & {$[0.0076]^{* *}$} & {$[0.0075]^{* *}$} \\
\hline \multirow[t]{2}{*}{$U * 4$ th pay quintile } & 0.0463 & 0.0455 & 0.0468 & 0.0461 \\
\hline & {$[0.0067]^{* *}$} & {$[0.0067]^{* *}$} & {$[0.0067]^{* *}$} & {$[0.0067]^{* *}$} \\
\hline \multirow[t]{2}{*}{$U * 5$ th pay quintile } & 0.0329 & 0.032 & 0.0333 & 0.0325 \\
\hline & {$[0.0084]^{* *}$} & {$[0.0084]^{* *}$} & {$[0.0084]^{* *}$} & {$[0.0084]^{* *}$} \\
\hline \multirow[t]{2}{*}{ 2nd pay quintile } & 3.8164 & 3.8093 & 3.8156 & 3.8082 \\
\hline & {$[0.038]^{* *}$} & {$[0.038]^{* *}$} & {$[0.038]^{* *}$} & {$[0.038]^{* *}$} \\
\hline \multirow[t]{2}{*}{ 3rd pay quintile } & 7.1956 & 7.1842 & 7.1939 & 7.1819 \\
\hline & {$[0.058]^{* *}$} & {$[0.058]^{* *}$} & {$[0.058]^{* *}$} & {$[0.058]^{* *}$} \\
\hline \multirow[t]{2}{*}{ 4th pay quintile } & 10.887 & 10.8744 & 10.8851 & 10.8718 \\
\hline & {$[0.147]^{* *}$} & {$[0.148]^{* *}$} & {$[0.147]^{* *}$} & {$[0.148]^{* *}$} \\
\hline \multirow[t]{2}{*}{ 5th pay quintile } & 16.1864 & 16.1712 & 16.1848 & 16.1692 \\
\hline & {$[0.19]^{* *}$} & {$[0.189]^{* *}$} & {$[0.188]^{* *}$} & {$[0.189]^{* *}$} \\
\hline \multirow[t]{2}{*}{ Intercept 5} & -13.2991 & -13.3564 & -13.325 & -13.3602 \\
\hline & {$[0.19]^{* *}$} & {$[0.195]^{* *}$} & {$[0.194]^{* *}$} & {$[0.195]^{* *}$} \\
\hline \multirow[t]{2}{*}{ Intercept 4} & -9.0486 & -9.1041 & -9.0745 & -9.1077 \\
\hline & {$[0.11]^{* *}$} & {$[0.115]^{* *}$} & {$[0.113]^{* *}$} & {$[0.115]^{* *}$} \\
\hline \multirow[t]{2}{*}{ Intercept 3} & -5.5852 & -5.6392 & -5.6110 & -5.6427 \\
\hline & {$[0.042]^{* *}$} & {$[0.041]^{* *}$} & {$[0.039]^{* *}$} & {$[0.040]^{* *}$} \\
\hline \multirow[t]{2}{*}{ Intercept 2} & -1.9467 & -1.9988 & -1.9724 & -2.0022 \\
\hline & {$[0.039]^{* *}$} & {$[0.039]^{* *}$} & {$[0.034]^{* *}$} & {$[0.035]^{* *}$} \\
\hline Quarter fixed effects + time trend & $\mathrm{X}$ & $\mathrm{x}$ & & \\
\hline Worker Characteristics & & $x$ & & $x$ \\
\hline Date fixed effects & & & $x$ & $x$ \\
\hline
\end{tabular}

+ significant at $10 \% ;{ }^{*}$ significant at $5 \% ;{ }^{* *}$ significant at $1 \%$

Notes: Sample is all workers with earnings in $t$ and $t+1$. We report estimates from ordered logits. Regressions also include state and industry fixed effects. When included, worker characteristics are a quadratic in age, a gender dummy, and job duration in quarters. Standard errors are clustered at the state level. 
Appendix Table 8: Job Matches over the Business Cycle

Dependent variable: Firm pay quintile in $t$

\begin{tabular}{l|cccc}
\multicolumn{1}{c}{} & I & II & III & IV \\
\hline State Unemp Rate (U) & -0.0173 & -0.0173 & -0.0257 & -0.0257 \\
Intercept 5 & {$[0.0023]^{* *}$} & {$[0.0023]^{* *}$} & {$[0.0071]^{* *}$} & {$[0.0071]^{* *}$} \\
& -2.9008 & -2.9017 & -2.8321 & -2.8328 \\
Intercept 4 & {$[0.059]^{* *}$} & {$[0.058]^{* *}$} & {$[0.092]^{* *}$} & {$[0.091]^{* *}$} \\
& -1.7933 & -1.7943 & -1.7245 & -1.7252 \\
Intercept 3 & {$[0.077]^{* *}$} & {$[0.076]^{* *}$} & {$[0.104]^{* *}$} & {$[0.103]^{* *}$} \\
& -0.8431 & -0.8441 & -0.7741 & -0.7748 \\
Intercept 2 & {$[0.119]^{* *}$} & {$[0.118]^{* *}$} & {$[0.142]^{* *}$} & {$[0.140]^{* *}$} \\
& 0.4482 & 0.4473 & 0.5174 & 0.5166 \\
\hline Quarter fixed effects + time trend & {$[0.147]^{* *}$} & {$[0.145]^{* *}$} & {$[0.165]^{* *}$} & {$[0.163]^{* *}$} \\
Worker Characteristics & $\mathrm{X}$ & $\mathrm{X}$ & & \\
Date fixed effects & & $\mathrm{X}$ & & $\mathrm{X}$ \\
\hline
\end{tabular}

+ significant at $10 \%$; $^{*}$ significant at $5 \%$; ${ }^{* *}$ significant at $1 \%$

Notes: Sample is all new matches in $\mathrm{t}$. We report estimates from ordered logits. Regressions also include state and industry fixed effects. When included, worker characteristics are a quadratic in age and a gender dummy. Standard errors are clustered at the state level. 


\section{Appendix Table 9: Firm Upgrading for New Matches \\ Dependent variable: Firm pay quintile in $t+3$}

\begin{tabular}{|c|c|c|c|c|}
\hline & I & II & III & IV \\
\hline \multirow[t]{2}{*}{ State Unemp Rate in t (U) } & -0.00608 & -0.00607 & -0.00959 & $\begin{array}{c}-0.00959 \\
{[0.00261 * *}\end{array}$ \\
\hline & $\begin{array}{c}{[0.0039]} \\
0.0117\end{array}$ & $\begin{array}{c}{[0.0039]} \\
0.0117\end{array}$ & $\begin{array}{c}{[0.0026]^{* *}} \\
0.0124\end{array}$ & $\begin{array}{c}{[0.0026]^{* *}} \\
0.0124\end{array}$ \\
\hline$U * 2$ nd pay quintile & {$[0.0047]^{*}$} & {$[0.0047]^{*}$} & {$[0.0047]^{* *}$} & {$[0.0047]^{* *}$} \\
\hline \multirow[t]{2}{*}{$\mathrm{U} * 3$ rd pay quintile } & 0.00943 & 0.00943 & 0.0102 & 0.0102 \\
\hline & [0.0073] & [0.0073] & [0.0073] & [0.0073] \\
\hline \multirow[t]{2}{*}{$\mathrm{U} * 4$ th pay quintile } & 0.00313 & 0.00313 & 0.00402 & 0.00402 \\
\hline & [0.0058] & [0.0058] & [0.0058] & [0.0058] \\
\hline \multirow{2}{*}{$U * 5$ th pay quintile } & -0.0419 & -0.0419 & -0.0413 & -0.0413 \\
\hline & {$[0.0099]^{* *}$} & {$[0.0099]^{* *}$} & {$[0.0099]^{* *}$} & {$[0.0099]^{* *}$} \\
\hline \multirow{2}{*}{ 2nd pay quintile } & 1.0684 & 1.0684 & 1.065 & 1.065 \\
\hline & {$[0.034]^{* *}$} & {$[0.034]^{* *}$} & {$[0.034]^{* *}$} & {$[0.034]^{* *}$} \\
\hline \multirow[t]{2}{*}{ 3rd pay quintile } & 1.9609 & 1.9609 & 1.9569 & 1.9569 \\
\hline & {$[0.047]^{* *}$} & {$[0.047]^{* *}$} & {$[0.047]^{* *}$} & {$[0.047]^{* *}$} \\
\hline \multirow[t]{2}{*}{ 4th pay quintile } & 3.0269 & 3.0269 & 3.0224 & 3.0224 \\
\hline & {$[0.073]^{* *}$} & {$[0.073]^{* *}$} & {$[0.073]^{* *}$} & {$[0.073]^{* *}$} \\
\hline \multirow[t]{2}{*}{ 5th pay quintile } & 5.3448 & 5.3448 & 5.3422 & 5.3422 \\
\hline & {$[0.11]^{* *}$} & {$[0.11]^{* *}$} & {$[0.11]^{* *}$} & {$[0.11]^{* *}$} \\
\hline \multirow[t]{2}{*}{ Intercept 5} & -4.4175 & -4.4167 & -4.3714 & -4.3703 \\
\hline & {$[0.082]^{* *}$} & {$[0.082]^{* *}$} & {$[0.075]^{* *}$} & {$[0.075]^{* *}$} \\
\hline \multirow[t]{2}{*}{ Intercept 4} & -2.8802 & -2.8793 & -2.8339 & -2.8328 \\
\hline & {$[0.041]^{* *}$} & {$[0.042]^{* *}$} & {$[0.034]^{* *}$} & {$[0.035]^{* *}$} \\
\hline \multirow[t]{2}{*}{ Intercept 3} & -1.7269 & -1.726 & -1.6806 & -1.6795 \\
\hline & {$[0.041]^{* *}$} & {$[0.041]^{* *}$} & {$[0.045]^{* *}$} & {$[0.045]^{* *}$} \\
\hline \multirow[t]{2}{*}{ Intercept 2} & -0.3759 & -0.3751 & -0.3294 & -0.3284 \\
\hline & {$[0.047]^{* *}$} & {$[0.047]^{* *}$} & {$[0.044]^{* *}$} & {$[0.043]^{* *}$} \\
\hline Quarter fixed effects + time trend & $x$ & $\mathrm{x}$ & & \\
\hline Worker Characteristics & & $\mathrm{x}$ & & $\mathrm{x}$ \\
\hline Date fixed effects & & & $\mathrm{x}$ & $\mathrm{x}$ \\
\hline
\end{tabular}

+ significant at $10 \% ;{ }^{*}$ significant at $5 \%$; ${ }^{* *}$ significant at $1 \%$

Notes: Sample is all new matches in $\mathrm{t}$. We report estimates from ordered logits. Regressions also include state and industry fixed effects. When included, worker characteristics are a quadratic in age and a gender dummy. Standard errors are clustered at the state level. 